\title{
Thermal treatment of Kalabsha kaolin deposits, south of the Western Desert, Egypt: contribution to geopolymer production as green building materials
}

\author{
Mohamed W. Abd El-Moghny ${ }^{1}$ Hatem M. El-Desoky ${ }^{1}$. Abdeen M. El-Nagar ${ }^{2} \cdot$ Nabil A. Abd El-Hafez ${ }^{1}$. \\ Hossam K. Sharaka ${ }^{3}$. Sayed A. Abouellaban ${ }^{3}$
}

Received: 21 January 2021 / Accepted: 7 February 2022 / Published online: 24 February 2022

(c) The Author(s) 2022

\begin{abstract}
Kaolin samples were collected to study the mineralogical, texture, chemical composition, thermal behavior, and treatment and also the possibility to convert kaolinite mineral into metakaolin and use it as a natural pozzolanic and/or as geopolymer materials. Kaolinite is the main constituent of clay mineral, which related to many of the chemical weathering of parent rocks and complete leaching of alkali elements under warm, humid to semi-arid climatic conditions. However, quartz, anatase, and iron oxide are considered non-clay minerals. Cement substituted by metakaolin under different ratios in the concrete industry was carried out to enhance the physical and mechanical properties of the concrete. The best results are detected at $10 \%$ and $15 \%$ of cement replacement by metakaolin. Geopolymer production using Metakaolin (MK) was mixed with $\mathrm{NaOH}$ and $\mathrm{Na}_{2} \mathrm{O}-3 \mathrm{SiO}_{2}$ to replace the Portland cement in the concrete industry and the obtained results are suitable and match with the green building material concept.
\end{abstract}

Keywords Metakaolin $\cdot$ Thermal treatment $\cdot$ Geopolymers $\cdot$ Concrete $\cdot$ Kalabsha $\cdot$ Egypt

\section{Introduction}

Kaolin deposits in Wadi Kalabsha, south of the Western Desert, Egypt are economically important as industrial materials, and geologically as indicators for paleoclimatic and depositional environments (Saber et al. 2018). The investigated area of Cretaceous kaolin deposits from the Wadi Kalabsha area is located at about $105 \mathrm{~km}$ southwest of Aswan City (about $17 \mathrm{~km}^{2}$ ), during Aswan-Abu Simple asphaltic road (Fig. 1). The studied area lies between latitudes $23^{\circ} 28^{\prime} 57.01^{\prime \prime}$ and $23^{\circ} 28^{\prime} 22.04^{\prime \prime} \mathrm{N}$ and longitudes $32^{\circ} 21^{\prime} 41.06^{\prime \prime}$ and $32^{\circ} 21^{\prime} 53.03^{\prime \prime}$ E. Kalabsha kaolin quarry

Responsible Editor: Zeynal Abiddin Erguler

Hossam K. Sharaka

hossam.sharaka_2014@yahoo.com

1 Geology Department, Faculty of Science, Al-Azhar University, Nasser City, Cairo P.O. Box 11884, Egypt

2 Housing and Building National Research Centre, Dokki, Giza, Cairo P.O. Box 11511, Egypt

3 Egyptian Mineral Resources Authority, Abbassiya, Cairo P.O. Box 11517, Egypt is considered the important resources of Egyptian kaolin, which comprise approximately 17 million metric tons. About 9,421,430 tons is of pisolitic type; $6,638,620$ tons is of concretional kaolin and 464,270 tons of the plastic (nonpisolitic) type. The production of kaolinite from the Kalabsha area $(\sim 60.000$ tons per year) is mainly for domestic uses such as ceramics, paper, refractories, and white cement (Baioumy and Gilg 2011; Embaby 2017).

El-Desoky et al. (2019) studied the availability of using clay materials of the upper Cenomanian El Heiz, TuronianSantonian Naqb El-Sillim, and Oligocene Radwan Formations in the Bahariya Oasis for the first time to use in the ceramic industry, especially vitrified clay pipes for sewers. They assigned that these raw materials are more appropriate for manufacturing the clay pipes because their clay materials are mainly kaolinite that needs the lowest water content during formation and this means low thermal energy in the drying process. Farouk et al. (2020) deliberate the rock units which contain high amounts of kaolinitic materials represented by the Malha, Naqb El-Sillim, and Abu Aggag formations of the Cretaceous age in the application for sewage clay pipes. They reported that the technological properties of the processed samples showed positive results for 
Fig. 1 Location and geological maps of Wadi Kalabsha area, south of the Western Desert, Egypt (modified after EGSMA, 2005)

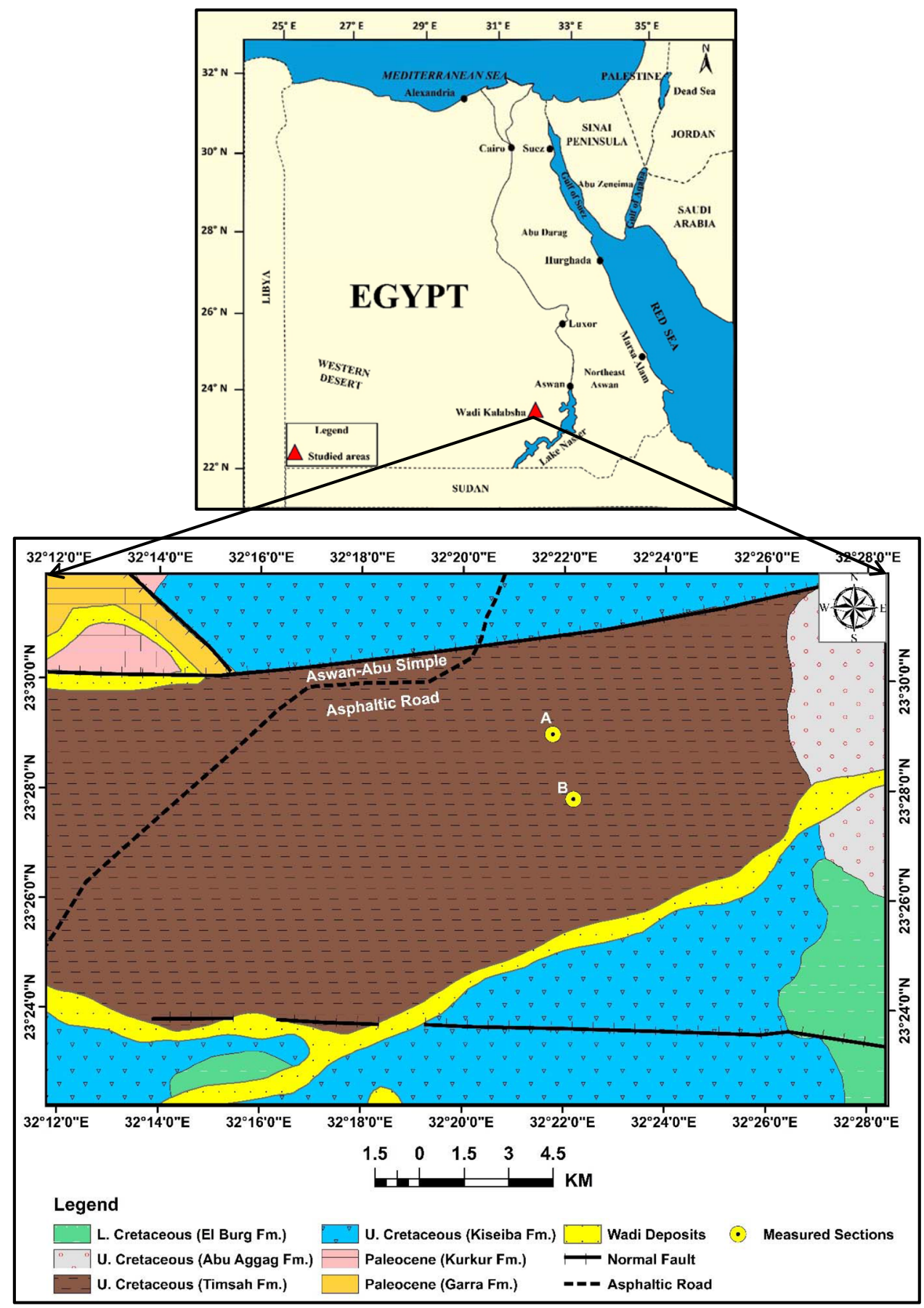

all requirements with the Naqb El-Sillim Formation; meanwhile, the Malha and Abu Aggag formations showed some negative results in water absorption and chemical resistance.

The cement substituted by MK improves the compressive strength of concrete due to the more consumption of $\mathrm{Ca}(\mathrm{OH})_{2}$, better pore refinement, micro filling action, early gain of strength, and higher pozzolanic reaction. It also helps in reducing the consumption of cement. This leads to the saving of natural resources and reduction in the emission of greenhouse gases like $\mathrm{CO}_{2}$ (Shakir et al 2013). The reaction of calcium hydroxide from Portland cement with natural pozzolan produces calcium-silicate hydrates $(\mathrm{C}-\mathrm{S}-\mathrm{H})$ and hardens the mortar and concrete. The partial replacement of pozzolan with cement initially reduces the rate of hardening of cement, but at later ages, the strength of Portland pozzolan cement is similar or 
sometimes higher than the corresponding control Portland cements, so Metakaolin is a very active natural pozzolan and can produce higher early strength concrete (Ali 2014).

The concrete in which replacement of cement by a mixture of silica fume and glass powder is its compressive strength is less than the control sample at 3 and 7 days curing and then increases its strength at 14 and 28 days curing. Meanwhile, glass powder and silica fumes are considered pozzolanic materials, and their reaction is started later. The increase in strength is due to the reaction of silica fume and glass powder with $\mathrm{Ca}(\mathrm{OH})_{2}$. This $\mathrm{Ca}(\mathrm{OH})_{2}$ is a byproduct that is produced during the cement hydration process and about $25 \% \mathrm{Ca}(\mathrm{OH})_{2}$ is formed (Abdul Ghayoor and Bazid 2017). Davidovits, a French scientist, created and applied the term "geopolymer" in 1979 to represent a kind of inorganic polymer with $\mathrm{SiO}_{4}$ and $\mathrm{AlO}_{4}$ tetrahedra being the structural units. The geopolymerization technology was introduced as an ideal and new environmentally friendly process for producing natural supplementary materials accomplished with OPC which were introduced by Davidovits (1988). Zain et al. (2017) assigned that the production of most standard types of geopolymer concrete has a slightly lower impact on global warming than standard OPC concrete. However, they also reveal that the production of geopolymer concrete has a higher environmental impact regarding other impact categories than global warming. This is due to the heavy effects of the production of the sodium silicate solution.

In general, geopolymers as a class of inorganic polymer is formed by a chemical reaction between an alkaline activator's solution and an aluminosilicate source (e.g., metakaolin). Although synthesis is similar, chemical bonding in OPC differs from geopolymers in that its former is formed by reactions of calcium oxide and silicon dioxide to form calcium-silicate hydrates, while geopolymers are formed by poly-condensation of $\mathrm{Al}$ and $\mathrm{Si}$ species (Provis et al. 2010; Hassaan et al. 2015; Khater and El Naggar 2019). The main constituent of geopolymer concrete is silicon and aluminum which are provided by thermally activated natural materials (e.g., Kaolinite) or industrial byproducts (e.g., fly ash) and an alkaline activating solution which polymerizes these materials into molecular chains and networks to create hardened binder (Shashikant and Prince Arulraj 2019). The geopolymer synthesizing technology is based on a mix of the alkaline activator with calcined kaolinite under relative temperatures as a source of aluminosilicate material in amorphous form (Davidovits 1999). Unlike Portland cement, water is not incorporated directly into the geopolymer gel product (Barbosa and Mackenzie 2003b). The increase in alkali activator, sodium hydroxide molarity, and sodium hydroxide to sodium silicate enhanced all of the mechanical properties, while the increase in alkaline solution/slag curing temperature has adversely affected the alkali-activated slag concrete (Ali et al. 2019).

Geopolymer is an exothermic process based on a polysialate framework structure with alternating $\mathrm{SiO}_{4}$ and $\mathrm{AlO}_{4}$ tetrahedra joined together in three directions. In general, geopolymerization consists of several processes including dissolution, reorientation, and solidification as shown in Fig. 2 (e.g., Davidovits 1991; Duxson et al. 2005 and 2007). Geopolymers have a wide range of microstructural changes due to their various types of raw sources, exposure conditions, and types of activators. Furthermore, the later age strength increase with increment of $\mathrm{Na}_{2} \mathrm{O} / \mathrm{SiO}_{2}$ ratio was due to a better binding mechanism involved in the alkali activation process (Lahiba et al. 2020). They assigned that three-factor affecting the properties of geopolymer concrete (GPC). These are the molarity of activators, curing temperature, and activator to binder ratio. Patankar et al. (2018)
Fig. 2 Sketch of a typical reaction mechanism of geopolymerization (Yao et al., 2009)

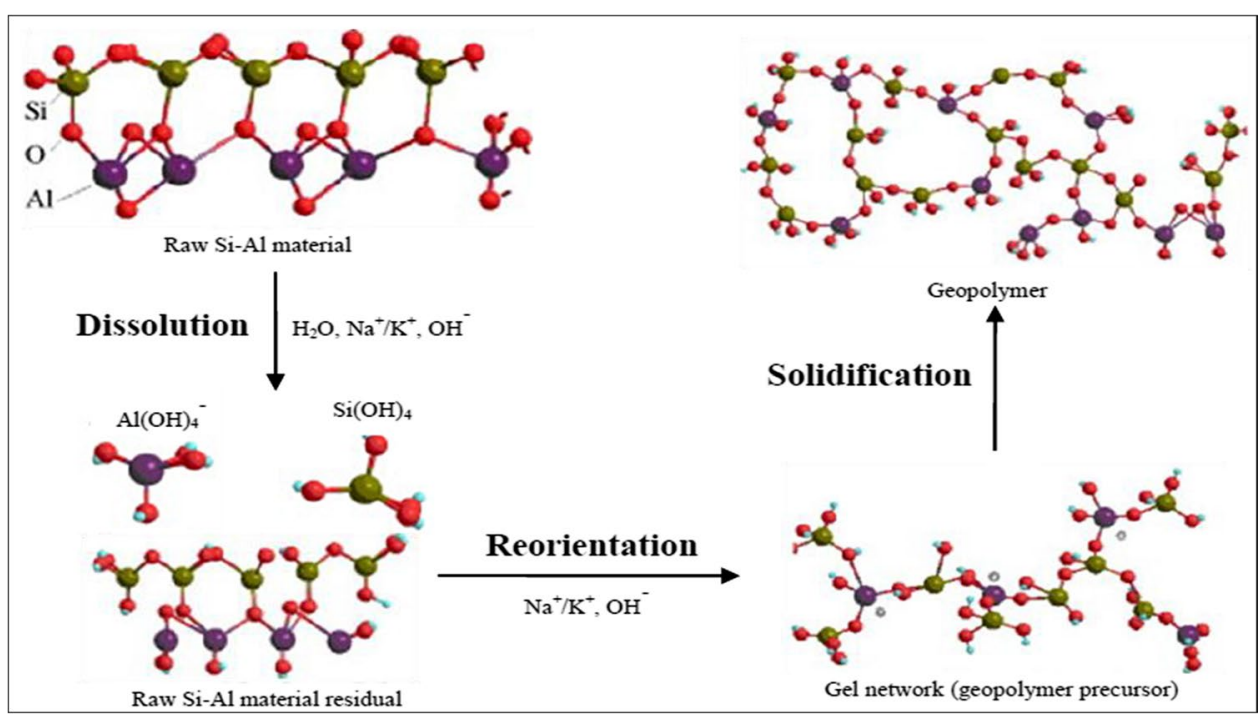


studied the effect of duration and temperature curing on compressive strength of geopolymer concrete and observed while finding the effect of concentration of sodium hydroxide on fly ash-based geopolymer concrete that the compressive strength of geopolymer concrete increases with an increase in the concentration of sodium hydroxide solution for all temperatures but the rate of gain of strength at and above $60{ }^{\circ} \mathrm{C}$ is not very significant. Geopolymer concrete is the most effective way to replace conventional concrete given economic and eco-friendly considerations. It is well suited for high-strength and high-performance concrete and it also has the resistance to chemical attacks (Vemundla and Koniki 2020). Nadhir et al. (2020) mentioned that the use of ground marble powder as a cement replacement up to $10 \%$ in the production of cement paste and mortar allows to reduce environmental problems and save more natural resources. In construction practice, it may be economically sensible to use marble powder as cement replacement for non-structural elements in a building; it can be used in tiles, edge sidewalks, and roof coating. This suggestion is due to the low density of marble powder compared to that of ordinary Portland cement.

The main objective of the present work is to study (1) the thermal treatment on the Kalabsha kaolin and convert it into Metakaolin (MK), (2) the effect of the addition MK as natural pozzolanic materials, and partially substituted ordinary Portland cement (OPC), and (3) the magnification of the Metakaolin role, as a geopolymer, in the green building material concept to study the preparation of geopolymeric materials using alkaline activators mixed with MK and amorphous water-cooled slag (ground granulated blast furnace) materials.

\section{Geologic setting}

The Wadi Kalabsha area and its environs were the subjects of several geological and geomorphological studies (e.g., El-Shazly 1954; Attia 1955; Issawi 1969, 1973, 1978, 1982, 1987; Said and Mansour 1971; Woodward-Clyde Consultants 1985; Youssef 1996; Baioumy and Gilg 2011; Embaby 2017; Hamimi et al 2018; Saber et al 2018).

Geographically, Wadi Kalabsha is located in the arid zone, characterized by long and dry summer when the day temperature normally reaches $50{ }^{\circ} \mathrm{C}$, and night temperatures reach $35^{\circ} \mathrm{C}$ (Said and Mansour 1971). The studied area is almost flat and covered by weathering products (Wadi wash and wind-blown sands), which usually make the outcrops of the kaolin beds. Few small-elevated ridges and hill rocks are scattered at the eastern and southern parts of the study area and are covered by hard quartzitic sandstone. El Kelany and Said (1990) divided the sedimentary section at Wadi Kalabsha, west of Lake Naser, from base to top into the following formations: Abu Simbil, Abu Ballas, El Burg, Kaolin Horizon, Alisa, and Nubia (Taref Sandstone Member). Said and Mansour (1971) subdivided the stratigraphic section at Wadi Kalabsha from the base to the top into three members, namely lower sandstone, Kalabsha kaolin, and upper sandstone. Germann et al. (1987) and Fischer (1989) referred that these members related to the Lower Cretaceous (Cenomanian) Timsah Formation according to the stratigraphic position, not to fossil contents. The dominant dip is towards the southeast at angles not exceeding $15^{\circ}$.

Structurally, the Kalabsha Fault Zone (KFZ) is not a single transcurrent wrench fault with a dextral sense of movement but, instead, it represents a major dextral transtensional shear or fault zone deforming southern Egypt and plays a significant role in the structural shaping of the area to the west of Nasser Lake. Two orthogonal nodal planes strike E to ENE, with subordinate right-lateral strike-slip component and $\mathrm{N}$ to NNW, with opposite left-lateral motion. Meanwhile, the directions of tectonic extension (T) and compression (P) are NNE-SSW and NNW-SSE, respectively (Hamimi et al 2018). The studied kaolin beds at the Wadi Kalabsha area range from a few centimeters to more than $4.5 \mathrm{~m}$ thick and are made up of white to earthy gray, hard, massive, compacted oolitic and pisolitic deposits. These kaolin beds belonged to Timsah Formation by Said and Mansour (1971) that overlie the sandstones of the Nubia Formation which is unconformably underlain by Precambrian basement rocks. Two stratigraphic sections were studied at the Wadi Kalabsha area, namely A and B to represent El-Timsah Formation which is unconformable overlie Abu Aggag Formation, and unconformable underlie Kiseiba Formation (Fig. 3).

The kaolin deposits at the studied section (A) are exposed in the lower part and can be distinguished into 3 beds. The lower bed is made up ( $4.5 \mathrm{~m}$ thick) of yellowish-white, hard, compact, pisolitic, and plastic kaolin deposits. It is overlain by nodular, dark gray to black kaolin bed (about $40 \mathrm{~cm}$ ) rich with plant remains. The uppermost kaolin bed $(60 \mathrm{~cm}$ thick) rests on the dark gray kaolin bed and is formed of grayishwhite, massive, semi-hard, compact kaolin (plastic) deposits. Also, it is covered by a thin-laminated, ferruginous sandstone bed and thick, yellowish-white, cross-bedded sandstones (Fig. 4a, b, c, and d). In the stratigraphic section (B), two kaolin beds have been measured (total thickness up to $1.3 \mathrm{~m}$ ) and described as grayish-white, massive, semi-hard, compact kaolin (plastic) deposits. These kaolin beds are intercalated by white to yellowish-white, semi-hard, compact, trough, and planner cross-bedded sandstones (ca. $\approx$ $80 \mathrm{~cm}$ thick) (Fig. 4e and f).

The studied kaolin deposits are considered a clastic deposit which is formed by the transportation of the intensely weathered parents' aluminous rocks and deposited in a closed aqueous body and divided into four main types depending on 
Fig. 3 General lithostratigraphic columnar sections A and B of the Lower-Upper Cretaceous sedimentary sequence in the south of the Western Desert, Kalabsha area, Egypt

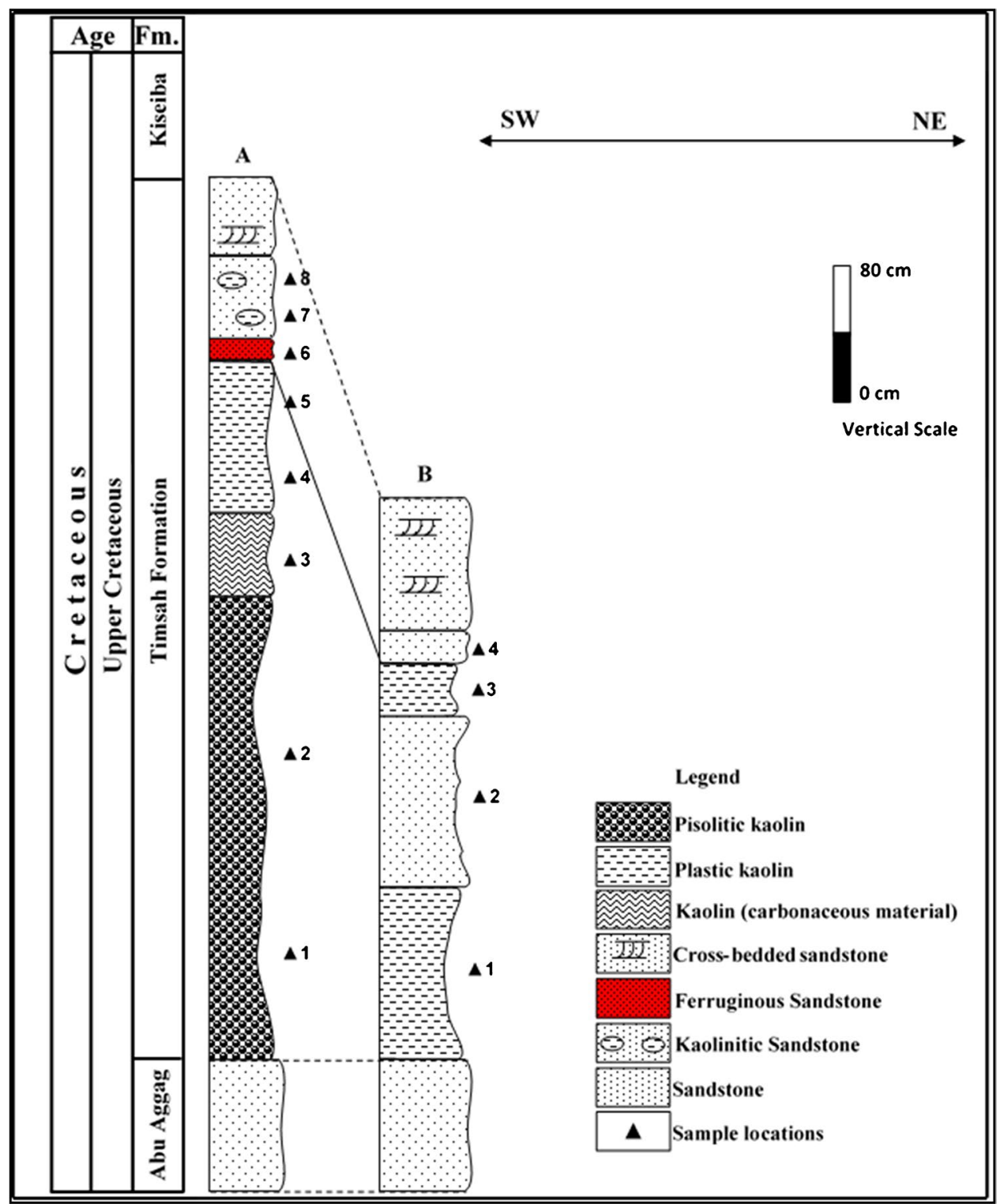

texture (Embaby 2017). These textures are particularly developed during early diagenesis in high alumina clays, such as bauxites and kaolinitic clays by Carozzi (1960). The bauxite deposits are formed by mechanical re-deposition in lakes and gulf-lagoonal parts with a considerable diagenetic reworking of the lateritic weathering products (Strakhov 1962). The studied kaolin related to direct weathering and alteration products of different rock types ranged from medium to high grade metamorphic mafic, granitic, and alkaline rocks (Baioumy and Gilg 2011). These kaolin deposits were formed by the in situ lateralization of the nearby basement complex (Youssef 1996). The kaolin deposits of hydrothermal origin have values of $\delta^{18} \mathrm{O}$ ranging from 2 to $14 \%$, whereas kaolin deposits that formed by surficial weathering have values of $\delta^{18} \mathrm{O}$ ranging from 15 to $19 \%$ and that of sedimentary origin have values of $\delta^{18} \mathrm{O}$ ranging from 19 to $23 \%$ by Murray and Janssen (1984).
The studied kaolin deposits have values of $\delta^{18} \mathrm{O}$ ranging from 16.3 to $18.2 \%$ and are related to direct surficial weathering (Youssef 1996).

\section{Materials and methods}

\section{Materials}

Two lithostratigraphic sections exposed at Wadi Kalabsha south of the Western Desert were measured, sampled, and in-detailed filed describe. Twelve samples were selected from the studied sections to identify their mineralogical, chemical composition, microstructure, and their thermal behavior of kaolinite samples. Geopolymer is based on natural materials such as calcined kaolinite (composite sample) 
Fig. 4 Field photographs showing kaolin deposits of El-Timsah Formation at Kalabsha area. a-d At section A. a Kaolinitic succession underlie cross-bedded sandstone separated by ferruginous kaolinitic sandstone bed. b Pisolitic (non-plastic) kaolin in El-Timsah Formation. c Pisolitic kaolin directly underlie cross-bedded sandstone with an absence of marker bed (ferruginous sandstone). d Dark gray kaolin bed with plant remains. $\mathbf{e}$ and $\mathbf{f}$ Intercalated between plastic kaolin and sandstone at section B
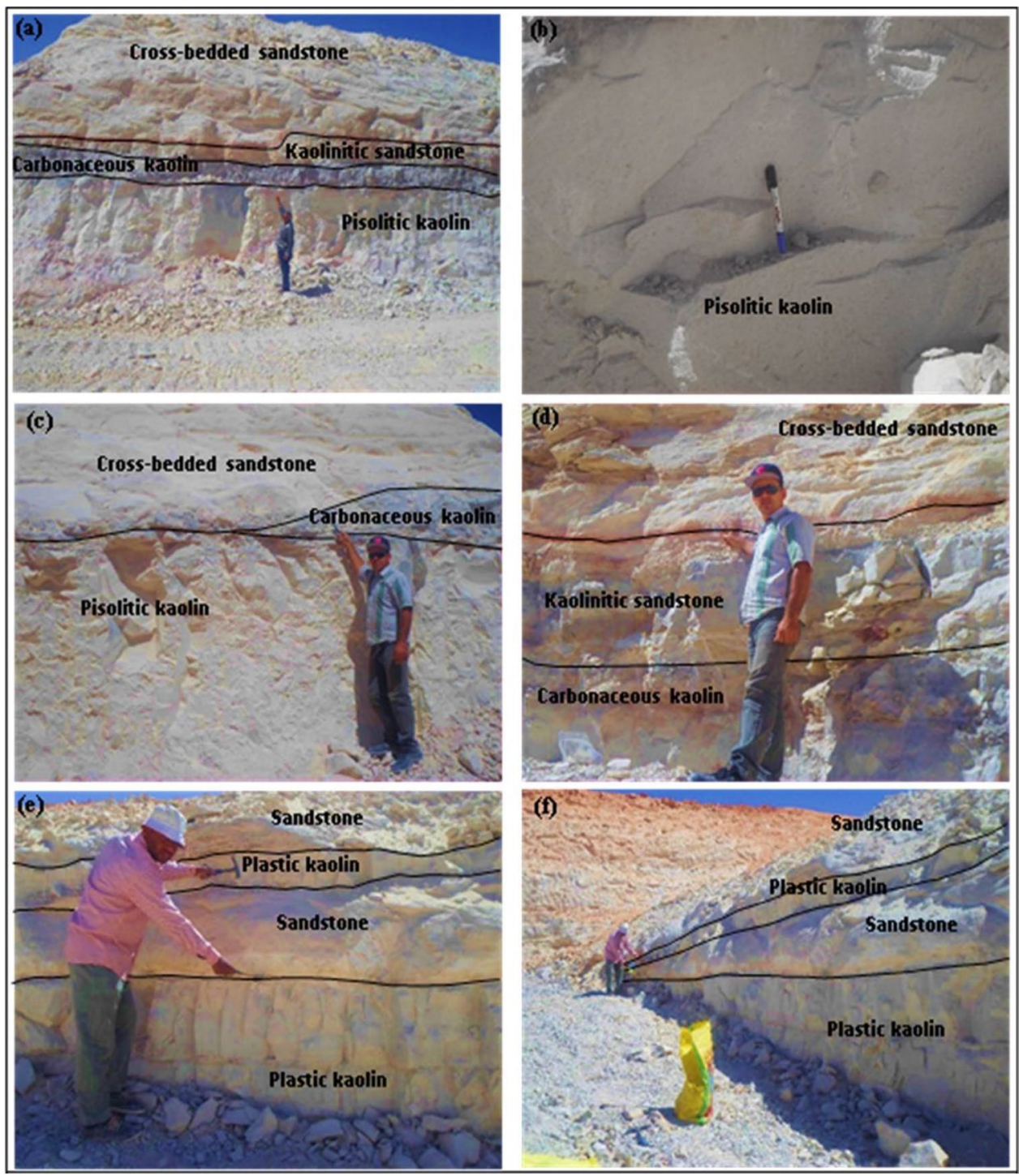

under temperatures ranging from 600 to $800{ }^{\circ} \mathrm{C}$ for $2 \mathrm{~h}$ under a heating rate of $5{ }^{\circ} \mathrm{C} / \mathrm{min}$. Water-cooled slag (ground granulate blast furnace slag-GGBFS) sourced from Iron and Steel Factory-Helwan, Egypt.

The alkali activators like sodium hydroxide $(\mathrm{NaOH})$ have purity of $96-100.5 \%$ in the form of pellets and sodium silicate $\left(\mathrm{Na}_{2} \mathrm{O}-3 \mathrm{SiO}_{2}\right)$ in the solution form $(26.5 \%)$. The activator solution was prepared by dissolving $10 \%$ by weight of cement of sodium hydroxide $(\mathrm{NaOH})$ pellets (in tap water due to the exothermic reaction) with sufficient water and stirred for $15 \mathrm{~min}$, and let until the solution was cooled down, then add $5 \%$ by weight of cement of sodium silicate $\left(\mathrm{Na}_{2} \mathrm{O}-3 \mathrm{SiO}_{2}\right)$ in solution form into the cooled sodium hydroxide solution. After that, the prepared geopolymeric activator solution was added to MK powder with slag. Then, pouring six cubes, two cubes of them were tested after 3 days, two cubes were tested after 7 days, and the last two cubes were tested for 28 days. The cubes were left to cure at room temperature for $24 \mathrm{~h}$ and then subjected to curing in an electrical oven at $60{ }^{\circ} \mathrm{C}$ and $80^{\circ} \mathrm{C}$ during different times. The samples were allowed to cool at room temperature for $2 \mathrm{~h}$ before being removed from the cubes. Then, the compressive strength tests on concrete geopolymers were applied at different ages.

According to ARACO SP30-Type G and SP20-Type F (highly effective superplasticizer for low water-cement concrete), the chemical additives with a dose range from 0.5 to $2 \mathrm{~kg} / 100 \mathrm{~kg}$ of cement content, which meets the requirements for ASTM C-494. The hyperplasticizer Glenium enhances the performance of concrete. It increases the concrete durability and water-reducing properties of supplementary cementitious materials (e.g., slag, fly ash, metakaolin, and microsilica) with a dosage of $0.5-1 \mathrm{~L}$ per $100 \mathrm{~kg}$ of cement content. The densities of the raw materials are fine aggregates 
around $2.65-2.67 \mathrm{~g} / \mathrm{cm}^{3}$, coarse aggregates $2.85 \mathrm{~g} / \mathrm{cm}^{3}$, cement $3.15 \mathrm{~g} / \mathrm{cm}^{3}$, and water $1 \mathrm{~g} / \mathrm{cm}^{3}$. Besides, the density of the chemical admixtures is around $1.064-1.8 \mathrm{~g} / \mathrm{cm}^{3}$. Also, the density of mineral admixtures like slag is $2.83 \mathrm{~g} / \mathrm{cm}^{3}$, Metakaolin is $2.6 \mathrm{~g} / \mathrm{cm}^{3}$, and kaolin is around $2.61-2.66 \mathrm{~g} /$ $\mathrm{cm}^{3}$, which are used as material compositions.

\section{Methods of investigation}

The intercalated sandstones (five samples) were described and sampled to study their petrographical characteristic by using a polarizing microscope of Leitz (ORTHOPLAN), type 307-148.002 max.100 W, Wetzlar, Germany. Eleven samples were examined (four sandstone samples and seven kaolin samples) with an X-ray diffraction analysis (XRD)automated powder diffractometer system of Philips type PanALytica equipment model X-Pert-PRO with Ni-filter, Cu-radiation $(\lambda=1.542 \AA)$ at $45 \mathrm{kV}, 35$ M.A., and normal scanning speed $0.03^{\circ}$ s. The reflection peaks between $2 \theta=2^{\circ}$ and $60^{\circ}$. The chemical concentration of major oxides is determined in the selected samples (four sandstone samples and seven kaolin samples) by using X-ray fluorescence (XRF) apparatus technique model Philips Pw/2404 at 30 Kwt. Both XRD and XRF analyses were carried out at the central laboratory sector of the Egyptian Geological Survey.

Differential thermal analysis (DTA) and thermogravimetric (TGA) analysis of the kaolinite samples was carried out at the Housing and Building National Research Center (HBRC) Cairo, Egypt, using computerized DT.50 thermal analyzers (Shimadzu Co., Kyoto, Japan). The heating rate was $20^{\circ} \mathrm{C} / \mathrm{min}$. The heating temperature was up to $1000^{\circ} \mathrm{C}$ for DTA and TGA under nitrogen atmosphere $(30 \mathrm{~mL} /$ $\mathrm{min})$. The internal structure of the studied kaolinitic samples was observed by scanning electron microscope (SEM) using SEM model QUANTA 250 FEG (field emission gun) attached with EDX unit (energy-dispersive X-ray analyses), with accelerating voltage $30 \mathrm{kV}$, magnification $14 \times$ up to $1,000,000 \times$, Netherlands. The type of detector used is the backscattering electrode, which was carried out at the central laboratory sector of the Egyptian Geological Survey. The graphics program was used to create the artwork (e.g., ArcGIS V.10.5; MS Office 2019 Word and Excel). Nine trail concrete samples were prepared, according to British Standard No. 1881-part 108 (1983), British Standard No. 12350-part 2 (2000), Egyptian Standard No. 1658-part 5 (1991), ASTM C-494 (2005), and C-192 (2007), by mixing a specified weight of coarse aggregate (dolomite), fine aggregate (sand), cement, and freshwater.

Determination of concrete workability used the slump test to detect the quality control level for the concrete mix as assigned by ASTM C-143 (2005), British Standard No. 12350-part 2 (2000), and Egyptian Standard No. 16Method for making cubes from fresh concrete is as58-part 1 (1988). Method for making cubes from fresh concrete is as per British standard No. 1881-part 108 (1983). The compressive strength for solid concrete samples was tested using a compression test machine (CTM) type Aimil-AEX.317EDG-STD-2000KN, fully automatic model (India) according to Egyptian standard no. 1658-part 5 (1991) and British standard-European Standard no.1881-part 115 (1986). The engineering test was carried out at the laboratories of the El-Bedaya Ready Mix Batch plant.

\section{Results}

\section{Petrographical examination}

Five thin sections of intercalated (thin layers) sandstone within kaolinite beds are examined using a polarizing microscope, to differentiate sandstone types and their mineralogical composition. The studied intercalated sandstone was classified petrographically according to Folk (1980). The petrographical examination revealed the presence of three sandstone types: quartz arenite, quartz greywacke, and laminated ferruginous quartz arenite. These are described as the following:

\section{Quartz arenite}

This sandstone type is dominated in the upper part (samples no. A8, B2, and B4) and is composed of yellowish-white, cross-bedded, semi-friable sandstone. Quartz grains form about $95 \%$ of the wall rock with view $(<5 \%)$ mica grains, mainly muscovite, which are partially altered into kaolin matrix. Quartz grains are mainly monocrystalline with some (ca. $\approx 7 \%$ ) polycrystalline, ill-sorted, occasionally medium to well-sorted, fine to coarse-grained, and rounded to angular, elongated to spherical shape (Fig. 5a). Quartz grains are affected by dissolution forming small groves reflecting the diagenetic effects of grains (Fig. 5 a-c).

\section{Quartz greywacke}

This sandstone type is developed in the upper part of the studied section A (sample no. A7). This lithofacies is composed of yellowish to grayish-white, massive, coarse to medium grain, hard to semi-hard sandstone. The thin section examination of this facies type revealed that this sandstone type is made up of sub-angular, fine to very fine, ill-sorted quartz grains that are scattered through the clay matrix. Quartz grains are mainly monocrystalline of igneous (granitic) origin and the effect of dissolution on some grains can be noted and forming small groves (Fig. 5d-f). 


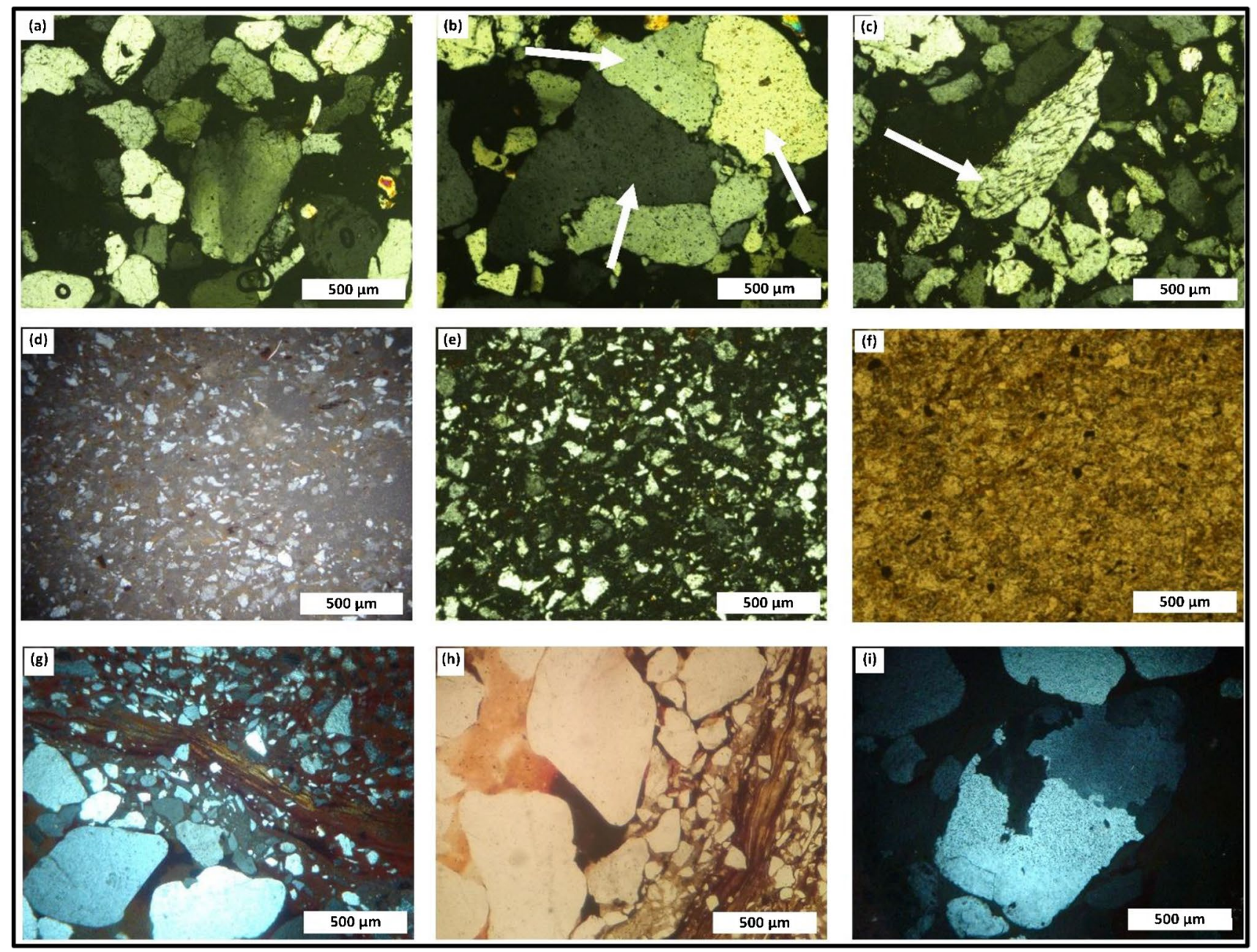

Fig. 5 Photomicrograph showing sandstone facies types. a-c Quartz arenite sandstone of El-Timsah Formation. b Polycrystalline quartz grains (arrows). c Groves in quartz grains affected by diagenetic dissolution. d-f Quartz greywacke sandstone type of sub-angular, fine to very fine and ill-sorted quartz grains. g-i Laminated ferruginous quartz arenite sandstone type where quartz grains are scattered in iron oxide cement

\section{Laminated ferruginous quartz arenite}

This sandstone type is recorded in the upper part of the ElTimsah Formation at Wadi Kalabsha (sample no. A6). It is composed of reddish to brownish yellow, compacted, massive, bedded, semi-hard, and medium to coarse-grained, ferruginous kaolinitic sandstone. Microscopically, this sandstone type is ill-sorted, sub-rounded to sub-angular, very fine to coarse-grained. Quartz grains are mainly monocrystalline and some crystals are polycrystalline texture (Fig. $5 \mathrm{~g}$-i). The matrix content forms up to $15 \%$ of the framework of this sandstone lithofacies. All framework grains are cemented by dark brown iron oxides, which may be formed by the chemical weathering of iron-rich minerals (e.g., biotite).

\section{Mineralogical and chemical composition}

The XRD study of bulk samples of the examined Upper Cretaceous deposits (Fig. 6) revealed that the studied kaolin samples are composed mainly of kaolinite and quartz with a few iron oxides and anatase as accessory minerals. The results of chemical analysis from investigated kaolinite samples revealed that these samples had a high concentration value of $\mathrm{Al}_{2} \mathrm{O}_{3}$ (average $36.76 \%$ ) and low content of $\mathrm{SiO}_{2}$ (average $45.65 \%$ ) due to the high content of kaolin and low quartz contents. $\mathrm{The}^{\mathrm{TiO}_{2}}$ and $\mathrm{Fe}_{2} \mathrm{O}_{3}$ contents are considerably high values (with an average of $3.5 \%$ and $0.71 \%$, respectively). This result indicates that it may be due to the ability of $\mathrm{Al}$ substitution by $\mathrm{Fe}$ and $\mathrm{Ti}$ ions in the kaolinite structure. On the other hand, the high LOI value reflects the high kaolinite quality and purity of the studied kaolin 
Fig. 6 The XRD pattern of the raw materials at A and B sections of the Cretaceous kaolin deposits at Wadi Kalabsha, south of the Western Desert, Egypt. Notice the symbols for rock-forming minerals taken from Kretz (1983) and Whitney and Evans (2010)

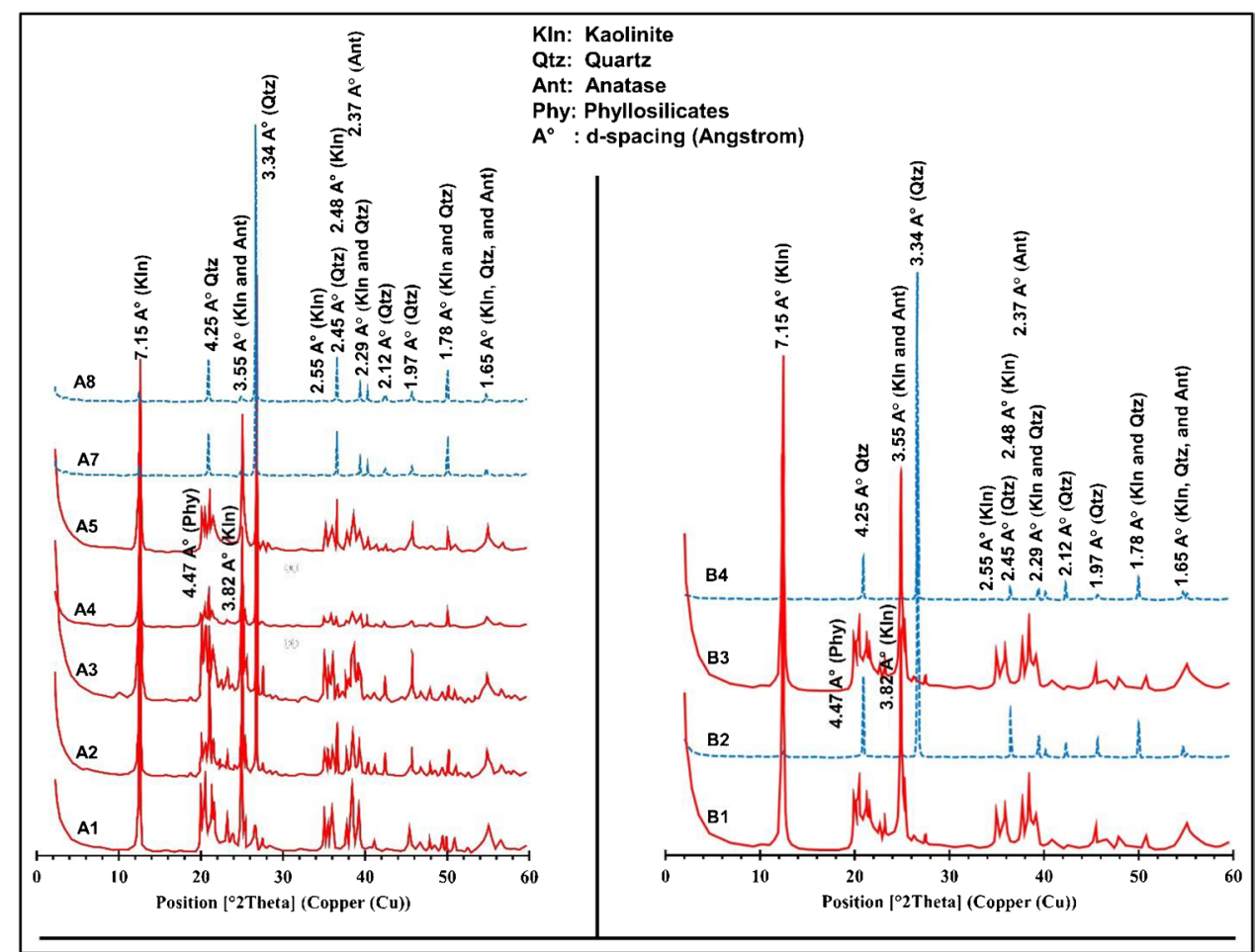

deposits (with an average of $12.85 \%$ ). Low $\mathrm{Ca}$, $\mathrm{Na}$, and $\mathrm{K}$ concentration values (average 0.09, 0.01, and 0.04, respectively) reflect the depletion of these alkali elements as shown in Table 1.

\section{Scanning electron microscope}

The kaolin samples were studied by the scanning electron microscope technique and revealed the presence of the individual kaolinite booklets arranged as face-to-face stacks of euhedral and pseudohexagonal plates or books
(Fig. 7 a-c). The hexagonal kaolinite plates occur either as discrete individual platelet or associated with the stacks. The investigated kaolinite sample lacks parallel orientation and face-to-edge fluctuation. Authigenic kaolinite growing on quartz crystal can be noted in Fig. $7 f$.

\section{Thermal behavior (TGA and DTA)}

The kaolinite mineral group undergoes a series of phase transformations upon thermal treatment in atmospheric pressure.
Table 1 Chemical composition (raw materials) of major oxides (wt\%) for the Upper Cretaceous (El-Timsah Fm.), Wadi

Kalabsha area, south of the Western Desert, Egypt

\begin{tabular}{llllllllllll}
\hline $\begin{array}{l}\text { Samples } \\
\text { Major oxides (wt\%) }\end{array}$ & $\mathrm{A} 1$ & $\mathrm{~A} 2$ & $\mathrm{~A} 3$ & $\mathrm{~A} 4$ & $\mathrm{~A} 5$ & $\mathrm{~A} 7$ & $\mathrm{~A} 8$ & $\mathrm{~B} 1$ & $\mathrm{~B} 2$ & $\mathrm{~B} 3$ & $\mathrm{~B} 4$ \\
\hline $\mathrm{SiO}_{2}$ & 45.62 & 46.83 & 44.58 & 47.39 & 45.25 & 77.16 & 87.75 & 44.57 & 92.06 & 45.29 & 88.65 \\
$\mathrm{TiO}_{2}$ & 2.53 & 4.35 & 3.39 & 5.45 & 3.79 & 2.13 & 0.45 & 3.53 & 0.36 & 2.02 & 0.78 \\
$\mathrm{Al}_{2} \mathrm{O}_{3}$ & 38.43 & 35.24 & 37.44 & 33.84 & 36.66 & 16.37 & 10.02 & 37.53 & 5.24 & 38.15 & 8.46 \\
$\mathrm{Fe}_{2} \mathrm{O}_{3}$ & 0.70 & 0.77 & 0.71 & 0.85 & 0.84 & 0.95 & 0.17 & 0.60 & 0.05 & 0.53 & 0.26 \\
$\mathrm{MnO}$ & 0.01 & 0.01 & 0.01 & 0.01 & 0.01 & 0.02 & 0.01 & 0.01 & 0.01 & 0.01 & 0.01 \\
$\mathrm{MgO}$ & 0.01 & 0.06 & 0.08 & 0.07 & 0.07 & 0.26 & 0.21 & 0.07 & 0.22 & 0.06 & 0.24 \\
$\mathrm{CaO}$ & 0.01 & 0.02 & 0.25 & 0.10 & 0.08 & 0.07 & 0.07 & 0.08 & 0.06 & 0.07 & 0.05 \\
$\mathrm{Na} \mathrm{O}_{2} \mathrm{O}$ & 0.01 & 0.01 & 0.01 & 0.01 & 0.01 & 0.04 & 0.15 & 0.01 & 0.07 & 0.01 & 0.13 \\
$\mathrm{~K}_{2} \mathrm{O}$ & 0.01 & 0.01 & 0.04 & 0.08 & 0.04 & 0.05 & 0.02 & 0.04 & 0.76 & 0.03 & 0.02 \\
$\mathrm{P}_{2} \mathrm{O}_{5}$ & 0.01 & 0.02 & 0.04 & 0.05 & 0.04 & 0.05 & 0.04 & 0.03 & 0.02 & 0.03 & 0.03 \\
$\mathrm{Cl}$ & 0.01 & 0.01 & 0.01 & 0.01 & 0.01 & 0.04 & 0.04 & 0.01 & 0.04 & 0.01 & 0.03 \\
$\mathrm{SO}_{3}$ & 0.01 & 0.01 & 0.01 & 0.01 & 0.01 & 0.04 & 0.04 & 0.01 & 0.03 & 0.01 & 0.03 \\
$\mathrm{L.O.I}$ & 12.42 & 12.49 & 13.27 & 11.99 & 12.99 & 2.56 & 0.83 & 13.30 & 0.80 & 13.52 & 1.06 \\
$\mathrm{Total}$ & 99.78 & 99.83 & 99.84 & 99.86 & 99.80 & 99.74 & 99.80 & 99.79 & 99.72 & 99.74 & 99.75 \\
\hline
\end{tabular}



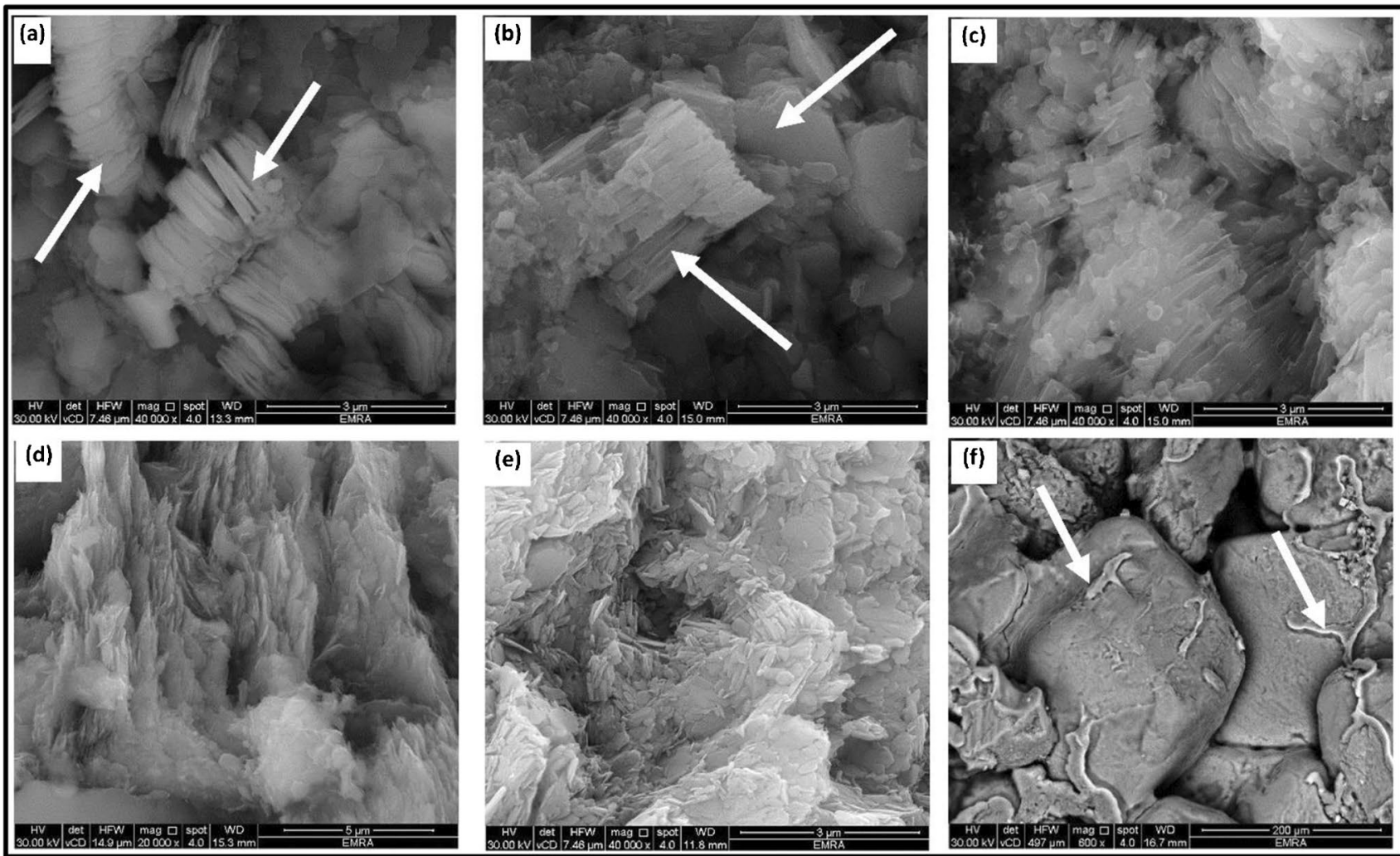

Fig. 7 a-c SEM showing face-to-face stacks of pseudohexagonal plates or books in vermicular shape. $\mathbf{d}$ Side view of a thick obscurely laminated packet of authigenic kaolinite. e Close up of kaolinite stacks. f Authigenic clay mineral (rim) on the surface of the quartz grains (arrows)

Below $100{ }^{\circ} \mathrm{C}$, exposure to dry air will slowly remove liquid water from the kaolin. At temperatures ranging from 100 to $550{ }^{\circ} \mathrm{C}$, liquid water was removed from kaolinite. The first endothermic peak around $90^{\circ} \mathrm{C}$ corresponds to an initial endothermic reaction for expelling of water into the upper surface, the one around $500-580{ }^{\circ} \mathrm{C}$ to de-hydroxylation of internal $(\mathrm{OH})$ groups, and the very sharp exothermic reaction peak around $1000{ }^{\circ} \mathrm{C}$ to recrystallization of the amorphous fraction generated through the de-hydroxylation and formation of $\gamma$ $\mathrm{Al}_{2} \mathrm{O}_{3}$ (Figs. 8 and 9). Földvári (2011) revealed that thermogravimetric analysis (TGA) and differential thermal analysis (DTA) are very important in all types of clay refractory since the rate of firing curve changes according to the points of decomposition and the points of loss in ignition.

\section{Micro-chemical and textural changes of MK (SEM- EDX)}

The morphology and micro-texture of the metakaolin body can be carried out by using the SEM technique (Welton 1984). The main constituent elements of the crystalline phases are determined by energy-dispersive X-ray (EDX) analysis on the spot, which helps in confining the identification of the crystalline phases. SEM morphology with
EDX micro-chemical analysis of metakaolinite yields the amorphous form with major elements $\mathrm{Si}$ and $\mathrm{Al}$ and minor amounts of $\mathrm{Ti}$ and $\mathrm{Fe}$ (Fig. 10). The amount of $\mathrm{Al}$ is variably related to the presence of small amounts from Ti and Fe may be substituted in the kaolinite structure.

\section{Industrial applications of MK}

\section{Partial substitution of cement by MK}

The main purpose of these experiments is to use MK to enhance the concrete properties by partial substitution of cement by different ratios of MK $(3,5,10,15$, and 20\%) by weight percent of cement. Reference (control) mix of cement and five mixes of different ratios of MK are shown in Table 2. Also, the compressive strength compared to the reference specimen with various percentages of metakaolin is presented in Fig. 11A. The third-day compressive strength result varied between 224 and $359 \mathrm{~kg} / \mathrm{cm}^{2}$. The 7-day compressive strength varied between 250 and $391 \mathrm{~kg} / \mathrm{cm}^{2}$. The 28-day strength varied between 304 and $498 \mathrm{~kg} / \mathrm{cm}^{2}$. On the other hand, the $5 \%$ replacement MK mixes exhibited lower strengths compared to the other MK percentages. The highest compressive strength results for the $10 \%$ and $15 \%$ MK 
Fig. 8 XRD pattern showing calcined kaolin after firing at $600{ }^{\circ} \mathrm{C}$

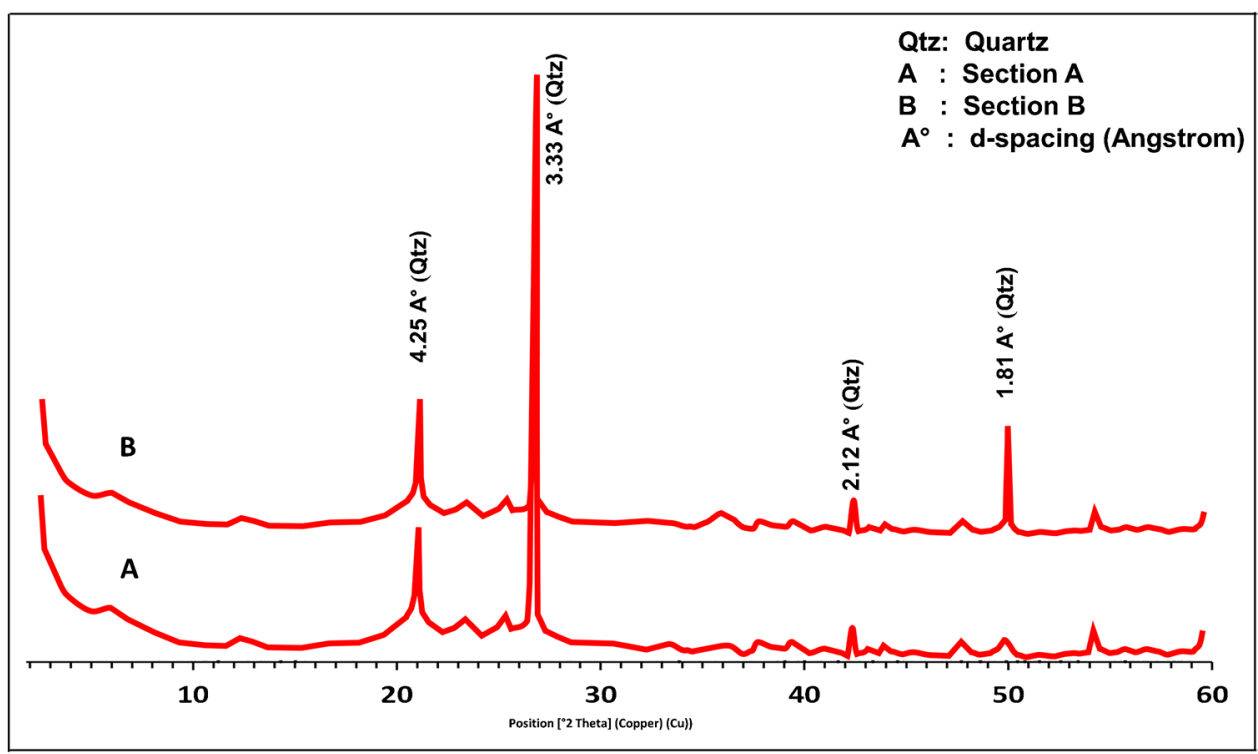

mix achieve 498 and $448 \mathrm{~kg} / \mathrm{cm}^{2}$, respectively at 28 days. The result of $20 \%$ MK replacement shows decreasing in compressive strength $\left(345 \mathrm{~kg} / \mathrm{cm}^{2}\right)$ at 28 days if compared with the control mix (Fig. 11).

\section{Mineral admixtures}

There is an effect of incorporating the MK with OPC under different ratios $(5,10$, and $15 \%)$ by weight of cement. These procedures consist of casting four trials to detect the effect of MK additives as natural pozzolanic on concrete properties. To obtain compressive strength results, the specimens are tested for 3, 7, and 28 days for reference (control) mix and specimens with MK under different ratios, and preparing six cubes for every trial and/or ratio as shown in Table 2 and Fig. 11B. The compressive strength results for all specimens incorporated MK by different ratios $(5,10$, and $15 \%)$ give the best result at $5 \%$ and $10 \%$ if compared with the reference mix. Adding MK improved compressive strength obviously since the incorporation of MK increases the compressive strength due to decreasing pore space (low permeability) and fast reactive nature, especially during the early ages of curing.

\section{Geopolymer concrete}

The main objective for the current work is to study the preparation of geopolymer composites using alkaline activators with Metakaolin and amorphous water-cooled slag material, and these are to enhance the understanding of this new type of building material. Geopolymer is a novel binder. Its manufacture consumes less energy and releases much lower $\mathrm{CO}_{2}$ in comparison to Portland cement. Geopolymer mortar or concrete is superior to normal concrete regarding durability. This result was introduced by Davidovits (1994). The total major oxides of MK and slag used in geopolymer concrete are tabulated in Table 3. Nevertheless, the mineralogical composition of MK and slag was done using X-ray diffraction analysis shown in Fig. 12. The pattern showed that water-cooled slag is composed mainly of amorphous materials, and minor content of the crystalline phases Akermanite mineral, while the metakaolin pattern reflects that mostly all the kaolin residues are distorted and dehydrated forming amorphous natural metakaolin material.

The percentages of MK and slag binder raw materials were taken from previous works by Khater et al. (2016). Mix designs for reference (control) mix and geopolymer specimens are mentioned in Table 4. After that pouring six cubes for compressive strength test results, the cubes were left to cure at room temperature for $24 \mathrm{~h}$. The compressive strength of MK and slag geopolymer at various curing times are plotted in Fig. 13. The compressive strength results of MK and slag geopolymer give values of 222,301 , and $367 \mathrm{~kg} / \mathrm{cm}^{2}$ after 3,7 , and 28 days, respectively. The geopolymer concrete gave similar results of compressive strength if compared to the results of the control mix.

\section{Geopolymer curing of mortars and pastes}

The proportions and some properties of geopolymer pastes are listed in Table 5 based on a previous investigation (Arioz et al. 2006; ASTM C-109 2012; Hassaan et al. 2015; Khater et al. 2016; Khater and El Naggar 2019). The geopolymer activator was mixed with slag, MK powder, and superplasticizer for $5 \mathrm{~min}$. The mixture was cast in $7 \times 7 \times 7 \mathrm{~cm}$ steel molds in two layers and vibrated for $30 \mathrm{~s}$ in each layer using a vibrating table. The molds were left to cure at room temperature for $24 \mathrm{~h}$ and then subjected to curing in an electrical oven at $60^{\circ} \mathrm{C}$ and 
Fig. 9 The differential thermal analysis (DTA) and thermogravimetric analysis (TGA) for kaolin samples were collected from Wadi Kalabsha, south of the Western Desert, Egypt

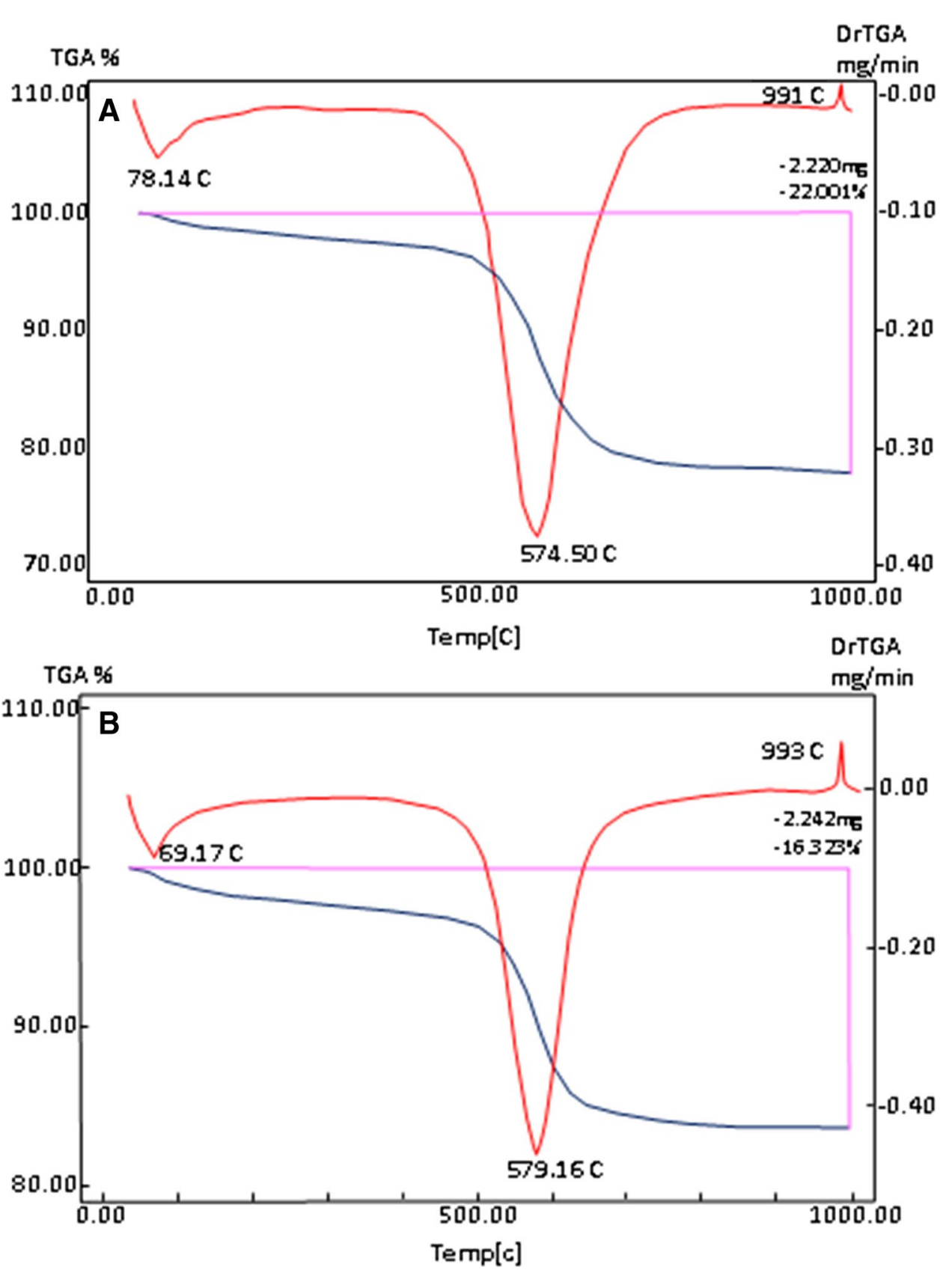

$80{ }^{\circ} \mathrm{C}$ during different times. The samples were allowed to cool at room temperature for $2 \mathrm{~h}$ before being removed from the molds. Influence of temperature and duration during curing on the geopolymer compressive strength test results is shown in Fig. 14. The strength of geopolymer pastes treated for $24 \mathrm{~h}$ is considerably higher than those treated for $6 \mathrm{~h}$. The test results of the geopolymer concrete show an increase in the curing time for all mixes, and all temperature degrees $60{ }^{\circ} \mathrm{C}$ and $80^{\circ} \mathrm{C}$. The compressive strength of geopolymer specimens subjected to $60{ }^{\circ} \mathrm{C}$ is slightly higher for all curing time. The highest values of compressive strength were obtained when treatment time was $60^{\circ} \mathrm{C}$ at $24 \mathrm{~h}$ in 28 days with paste mix composed of MK and slag materials (Fig. 14).

\section{Discussion}

The sandstones may form an important source of clay minerals depending on their mineral constituents, porosity, permeability, and depositional facies. Such sedimentary structures, as planar tabular and trough cross-bedding, are developed in sandstones of the studied sections of the Kalabsha area. These sedimentary structures indicate fluvial depositional environments of the El-Timsah Formation. Youssef (1996) described some lag deposits, scour, and fill structures within the sandstones at the Kalabsha area that indicate their deposition by sinuosity or braided rivers. 
Fig. 10 The EDX analysis spot (yellow circle) and SEM morphology of amorphous Metakaolin (MK) yields the major elements $\mathrm{Si}$ and $\mathrm{Al}$ with a minor amount of $\mathrm{Ti}$ and $\mathrm{Fe}$

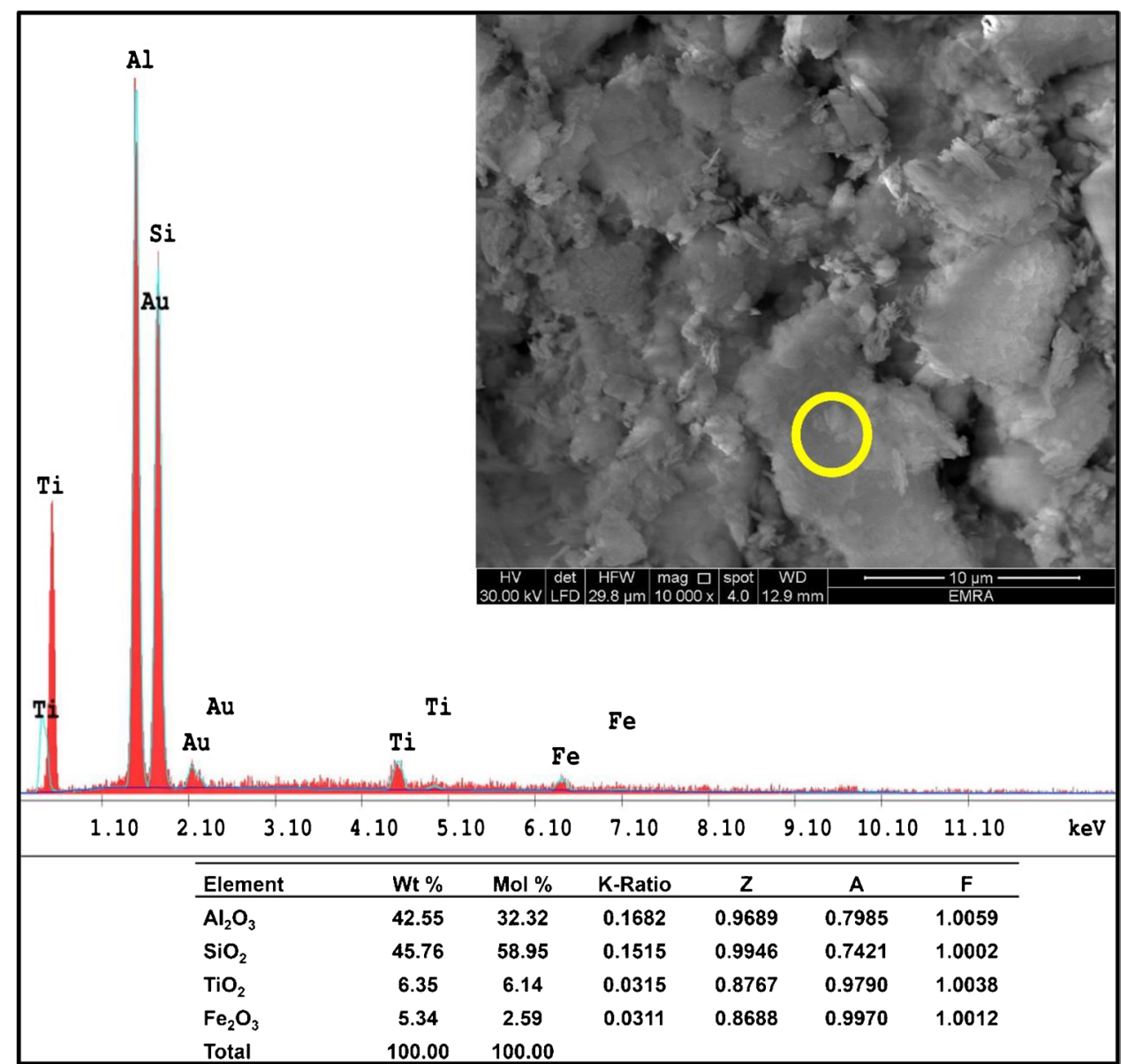

Table 2 Mix design contents of partial replacement and mineral additives by weight of cement

\begin{tabular}{|c|c|c|c|c|c|}
\hline \multicolumn{6}{|l|}{ Trials mix design } \\
\hline Raw material (kg) & $\begin{array}{l}\text { Material } \\
\text { densities } \\
\mathrm{g} / \mathrm{cm}^{3}\end{array}$ & $\begin{array}{l}\text { Reference (control) mix } \\
\text { C25/350 }\end{array}$ & Cement substitution & $\begin{array}{l}\text { Reference (control) mix } \\
\text { C40/450 }\end{array}$ & Mineral admixtures \\
\hline $\begin{array}{l}\text { Coarse aggregates (dolo- } \\
\text { mite) }\end{array}$ & 2.85 & $33.600 \mathrm{~kg}$ & & & \\
\hline Fine aggregate (sand) & 2.65 & $21.750 \mathrm{~kg}$ & & $20.100 \mathrm{~kg}$ & \\
\hline Cement (OPC) & 3.15 & $10.500 \mathrm{~kg}$ & & $13.500 \mathrm{~kg}$ & \\
\hline \multirow[t]{5}{*}{ Metakaolin (MK) } & 2.6 & & $3 \%(315) \mathrm{gm}$ & & $5 \%=(675) \mathrm{gm}$ \\
\hline & & & $5 \%(525) \mathrm{gm}$ & & $10 \%=(1.350) \mathrm{kg}$ \\
\hline & & & $10 \%(1.050) \mathrm{kg}$ & & $15 \%=(2.025) \mathrm{k}$ \\
\hline & & & $15 \%(1.575) \mathrm{kg}$ & & \\
\hline & & & $20 \%(2.100) \mathrm{kg}$ & & \\
\hline Water & 1 & $6 \mathrm{~L}$ & & $5.5 \mathrm{~L}$ & \\
\hline Chemical additives & 1.175 & SP30-Type $G=(210$ gm $)$ & & SP20-Type $F=(270$ gm $)$ & \\
\hline
\end{tabular}

Five kaolin beds were well developed in the studied Kalabsha area. The two beds in section B as well as the uppermost kaolin bed in section A consist of grayish-white, massive, semi-hard, compact kaolin (plastic) deposits in a nodular or lens shape, and attain up to $1.3 \mathrm{~m}$ thick, while the lower bed (up to $4.5 \mathrm{~m}$ thick) in section A can be described as yellowish-white, hard, compact, pisolitic, and plastic kaolin sediments. This pisolitic kaolin bed is overlain by dark gray to black kaolin bed rich in plant remains. The topmost part of the upper kaolin bed is separated from its overlying 
Fig. 11 The correlation between compressive strength results for natural pozzolanic at different ratios. A Chart shows compressive strength against age and ratios for cement substitution. B Chart represents the effect of the mineral additive into fresh concrete with compressive strength $(\mathrm{RM}=$ reference mix $)$

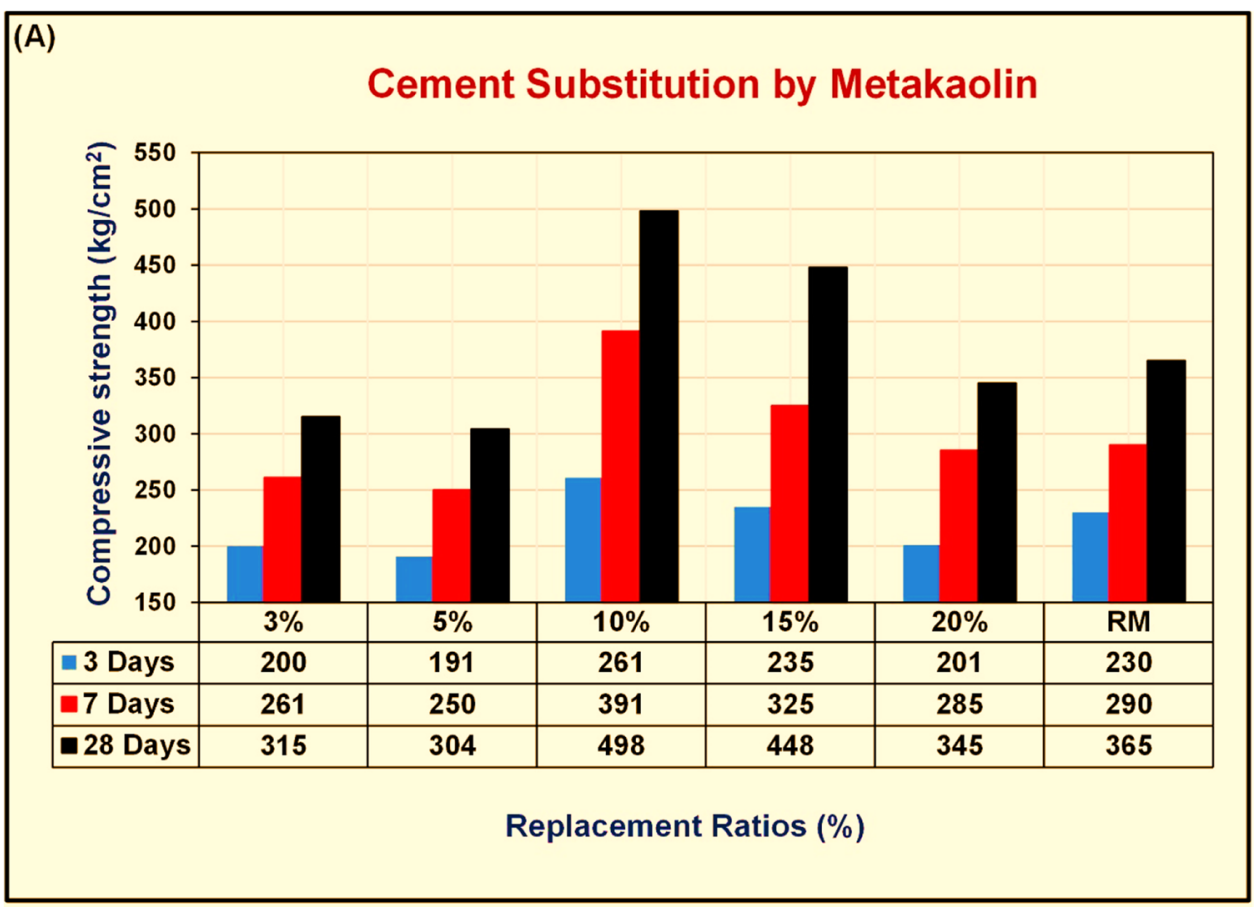

(B)

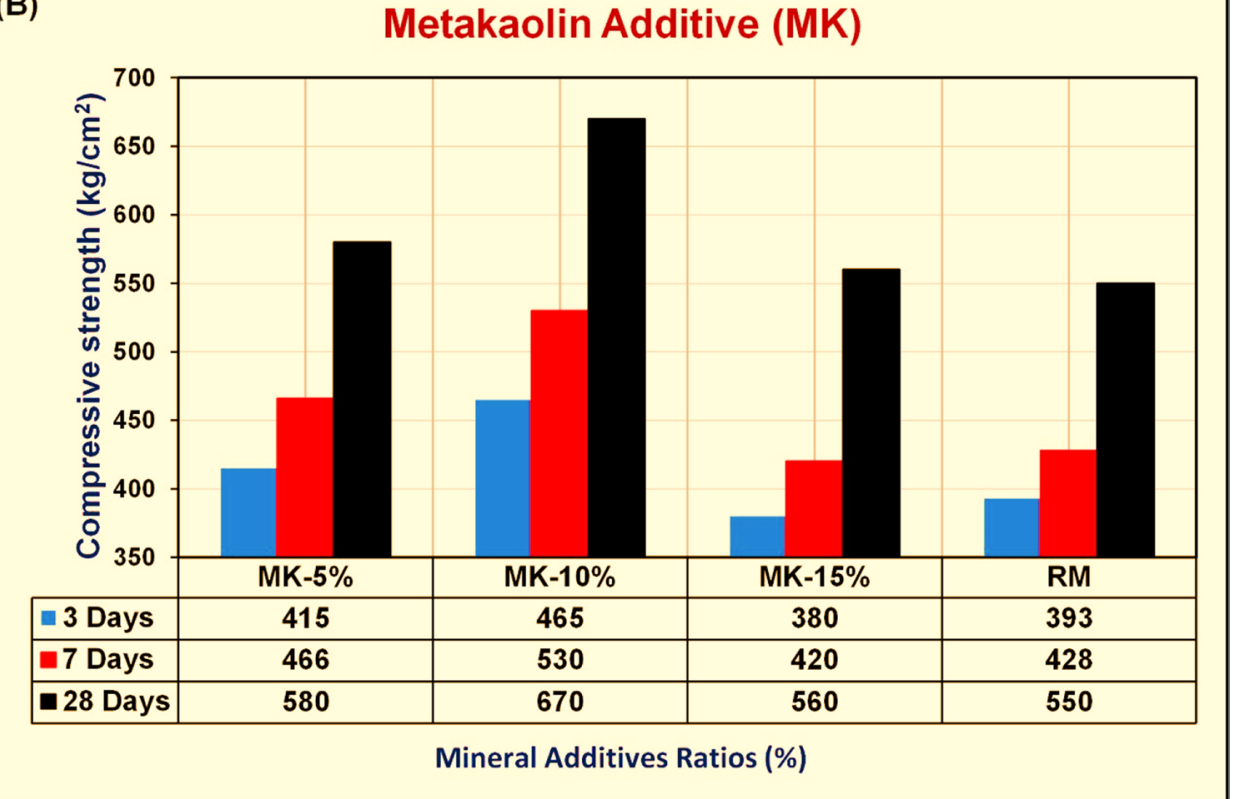

Table 3 Chemical analysis of major oxides (wt \%) of natural materials used in geopolymer composites

\begin{tabular}{|c|c|c|c|c|c|c|c|c|c|c|c|c|c|c|c|}
\hline Oxides & $\mathrm{SiO}_{2}$ & $\mathrm{TiO}_{2}$ & $\mathrm{Al}_{2} \mathrm{O}_{3}$ & $\mathrm{Fe}_{2} \mathrm{O}_{3}$ & $\mathrm{MnO}$ & $\mathrm{MgO}$ & $\mathrm{CaO}$ & $\mathrm{Na}_{2} \mathrm{O}$ & $\mathrm{K}_{2} \mathrm{O}$ & $\mathrm{P}_{2} \mathrm{O}_{5}$ & $\mathrm{Cl}$ & $\mathrm{SO}_{3}$ & L.O.I & Total & Densit \\
\hline & 3.92 & 6.09 & 40.84 & 5.13 & 0.01 & 0.02 & & 0.01 & 0.01 & 0.01 & 0.01 & 0.01 & 2.11 & 98.18 & 2.6 \\
\hline Slag (GGBFS) & 35.01 & 0.49 & 11.65 & 1.08 & 3.9 & 5.81 & 35.12 & 1.07 & 0.84 & 0.06 & 0.11 & 2.77 & 0.07 & 97.98 & 2.83 \\
\hline
\end{tabular}

sandstone by reddish-brown, yellow, ferruginous gravelly sandstones reflecting a period of subaerial exposition, nonaccumulation, and the effect of chemical weathering.
The lens shape kaolin deposits interfingering with sandstone in the sequence represent paleosols truncating the alluvial plain adjacent to the stream channels (Youssef 1996). According to Germann et al. (1987), the nodular kaolin bed 
Fig. 12 X-ray diffraction pattern of geopolymer materials

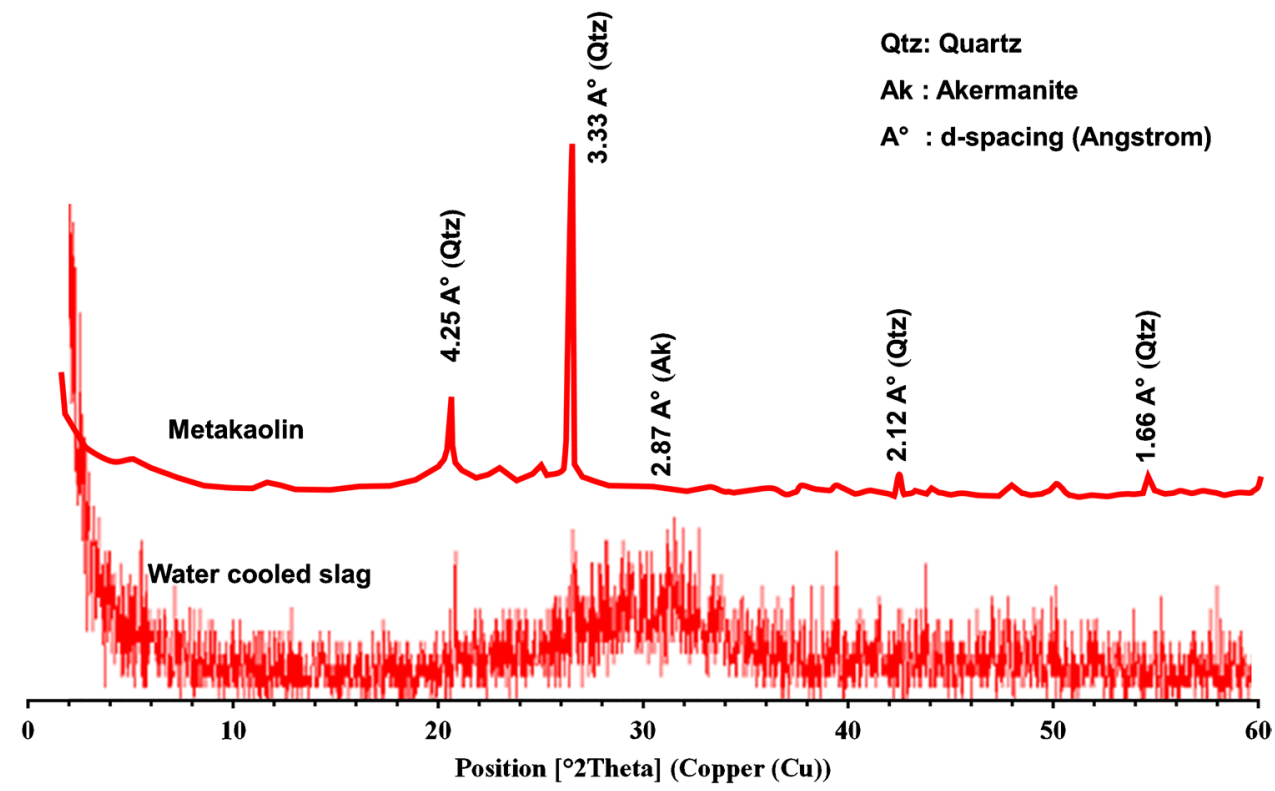

Table 4 The mix design of reference mix and geopolymer concrete

Mix design for geopolymer concrete (materials $\left(\mathrm{kg} / \mathrm{m}^{3}\right)$ )

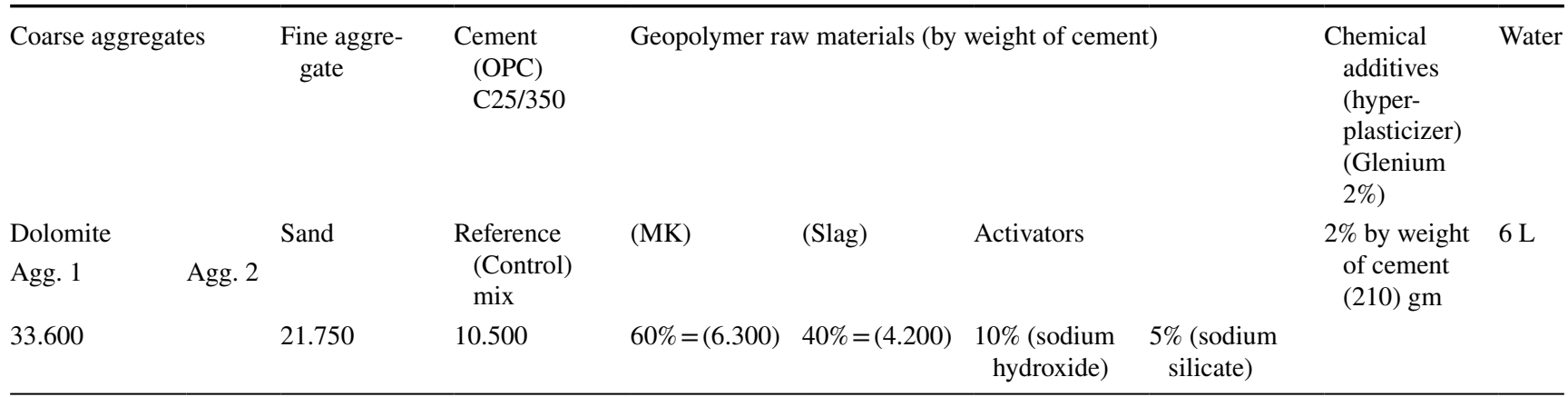

Fig. 13 The comparison between compressive strength results of reference mix (C25) and geopolymer concrete $(\mathrm{RM}=$ reference $\mathrm{mix})$

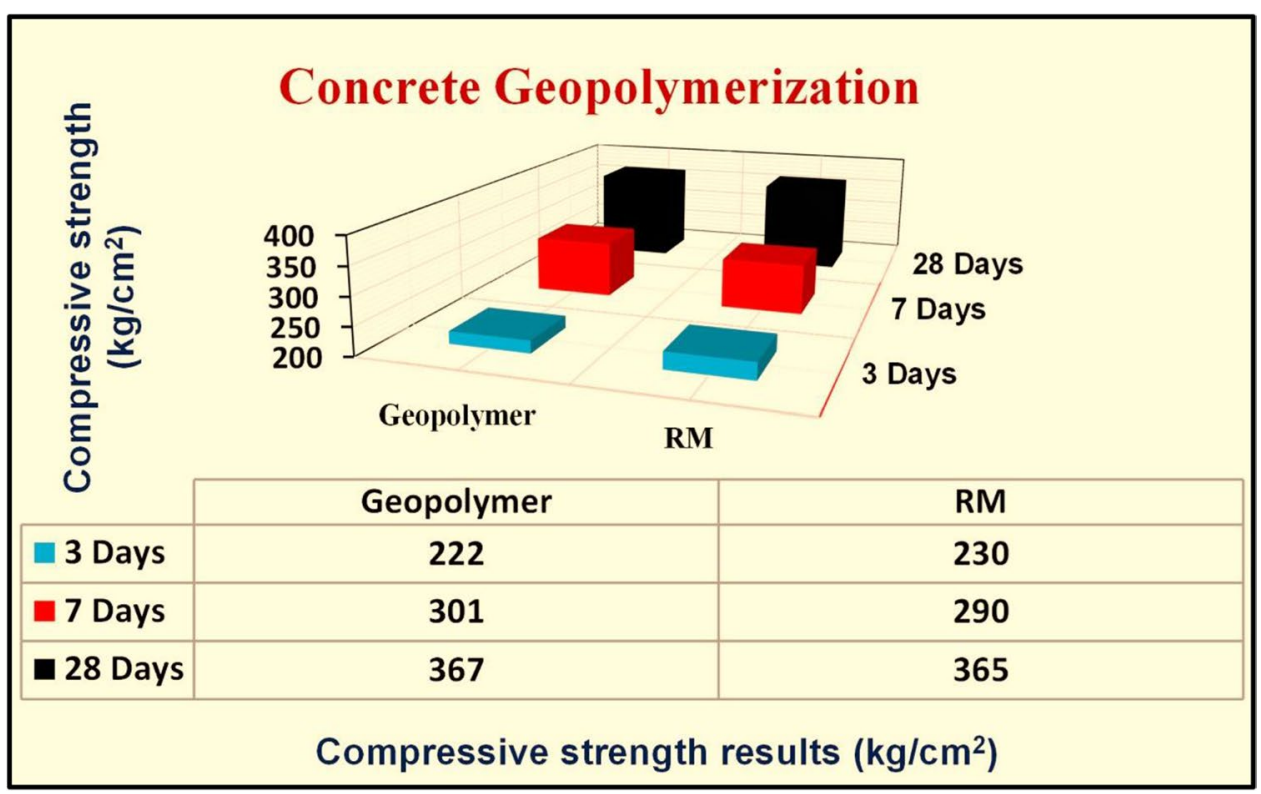


Table 5 The proportion of the studied mix of geopolymer pastes and curing processes

\begin{tabular}{|c|c|c|c|c|c|c|}
\hline \multicolumn{7}{|c|}{ Mix design for mortar and pastes (materials (gm)) } \\
\hline Mix no & Metakaolin & Sand & Slag & Sodium hydroxide & Sodium silicate & Hyperplasticizer (Glenium) \\
\hline 1 & 1000 & -- & - & 100 & 50 & $2 \%$ \\
\hline 2 & 600 & 300 & 400 & & & \\
\hline 3 & 600 & -- & 400 & & & \\
\hline 4 & 700 & 300 & - & & & \\
\hline \multicolumn{7}{|c|}{ Time-temperature curing processes } \\
\hline & \multicolumn{3}{|l|}{ Time (hours) } & & \multicolumn{2}{|l|}{ Temperature $\left({ }^{\circ} \mathrm{C}\right)$} \\
\hline 1 & \multicolumn{3}{|l|}{6} & & \multicolumn{2}{|l|}{80} \\
\hline 2 & \multicolumn{3}{|l|}{24} & & \multicolumn{2}{|l|}{60} \\
\hline
\end{tabular}

Fig. 14 The compressive strength results of geopolymer paste specimens: (1) showing paste specimens of MK; (2) paste specimens of MK with slag and sand; (3) paste specimens of MK with slag; (4) paste specimens of MK and sand

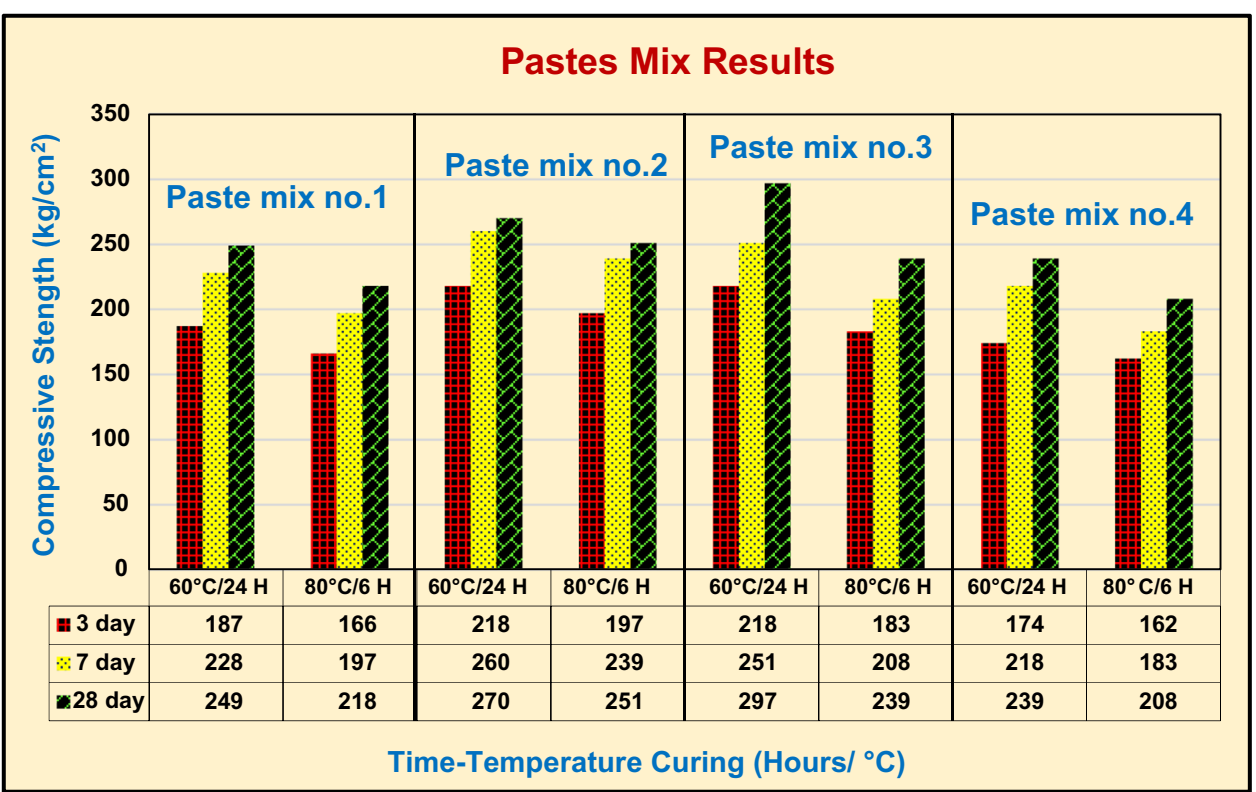

at the studied Kalabsha area is deposited by mass wasting, while the upper pisolitic kaolin bed formed as fluvial clastic deposits. El-Askary (1992) pointed out that the pisolitic kaolin bed at Kalabsha area was formed inorganically from detrital kaolinite-iron hydroxide colloid coagulates during early subaqueous diagenesis in agitated conditions. Baioumy and Gilg (2011) described the lithostratigraphic succession and pisolitic texture of the Kalabsha kaolin and recorded corroded quartz, depletion of many trace elements, unusual grain size distribution, and compositional homogeneity. They suggested a lateritic precursor of these pisolitic kaolin deposits, where the lateritic precursor sediments have been deferated and resilicified in the sedimentary basin to form these whitish clays. Besides, the textural and geochemical variations referred that the overlying plastic clays are not formed by reworking of the pisolitic kaolin, but are derived from the saprolites underlying the lateritic crusts in the source region (sequential stripping).

Texturally, the studied sandstones of El-Timsah Formation are made up of ill-sorted, occasionally well to moderately sorted, fine to coarse-grained, and rounded to angular, elongated to spherical shape tend to moderately porosity volume, and permeability, and permitted the passage of solutions containing dissolved silica and alumina derived from the source area. The petrographic and mineralogical examinations of the studied sandstone referred presence of three sandstone types including quartz arenite, quartz greywacke, and ferruginous quartz arenite. These sandstones are mainly composed of quartz, kaolinite, and anatase, as an accessory mineral, with depleted mica and feldspars due to their alteration to kaolinite. The detected anatase mineral in the studied kaolin samples may be related to their diagenetic origin. Anatase is a diagenetic product formed during and after deposition of sandstone as an authigenic mineral (Folk 1980) and can be concentrated in sedimentary kaolin deposits (Railsback 2003).

The XRD analyses of the sandstones and kaolinite samples revealed a sharp, narrow peak pattern of high-ordered authigenic kaolinite. Scanning electron microscope (SEM) detected the stacks of kaolinite texture and sinuous kaolinite 
structure (vermiform) that reflects the authigenic nature of kaolinite through fresh groundwater and tropical conditions. Hinckley (1965) referred to the presence of the long sinuous forms to authigenic development of the kaolinite mineral. The vermiform kaolinite occurs in modern soils in the tropics (Fitzpatrick 1980). Bentabol et al. (2006) pointed out that muscovite neomorphosis and kaolinite authigenesis are the first diagenetic modifications in most of the non-marine sediments, and are the products of freshwater diagenesis. The predominance of platy stacks of kaolinite texture revealed a long time and slow recrystallization process, while rapid precipitation of kaolinite minerals leads to spherical morphologies.

At $10 \%$ and $15 \%$ cement substitution, the compressive strength results increase by a significant amount (36 to $22.7 \%$, respectively) if compared to the control mix. On the other hand, the compressive strength result at $20 \%$ cement replacement is decreased if compared to the control mix. The reactions between the oxides of silicon, aluminum, ferrous iron, and calcium in the cement and pozzolanic metakaolin increase the strength of concrete mix with metakaolin, where these materials complemented each other by contributing oxides of the mentioned metals in substantial quantity to the concrete (Akinyele et al. 2017). The decreasing of strength at 20\% metakaolin replacement in the control mix can be referred to as the high $\mathrm{Al}$ content more than the available reactive $\mathrm{Ca}$ content in the concrete. According to Wild et al. (1996) and Akinyele et al. (2017), the amount of metakaolinite may be probably too high and over the quantity of the produced calcium hydroxide from the hydration of cement. Therefore, this action produces an immediate dilution effect and the water-cement ratio is reduced.

Mineral admixtures (e.g., MK) to control mix revealed that the compressive strength results increased by approximately $22 \%$. Adding MK can act as filler material and improve compressive strength due to decreasing pore space and fast reactive nature, especially during the early ages of curing. The filler effect resulted in dense filling capacity at the aggregate/paste interface and therefore enhanced the density of the metakaolin concrete (Sabir et al. 2001). The obtained compressive strength results of MK and slag geopolymer gave similar results of compressive strength if compared to the results of the control mix, and the compressive strength increase in all mixes along with curing time attributed to the continuous pozzolanic reaction of slag and MK pastes. The curing temperature (approximately $60{ }^{\circ} \mathrm{C}$ for at least $24 \mathrm{~h}$ ) is similar to that was accomplished by Hassaan et al. (2015) and Connie et al. (2018). The good results may be since highly reactive MK consumes the liberated hydrated lime from hydration reaction and results in the formation of $\mathrm{CSH}$ that act as nucleating sites for geopolymer formation.

\section{Environmental impact}

The cement substituted by Metakaolin (10\% and 15\%) in the concrete industry was carried out to enhance the physical and mechanical properties of the concrete. The experimental data of the studied Metakaolin revealed optimum results in compressive strength and workability. Metakaolin is considered a source of supplementary cementation materials to reduce both $\mathrm{CO}_{2}$ emissions and the energy consumption used in cement production (Tironi et al. 2012). The use of metakaolin instead of cement in ready-mixed concrete has many important characteristics as (1) reducing the required industrial energy where the clinker is burned at $1450{ }^{\circ} \mathrm{C}$, while metakaolin is produced at $750{ }^{\circ} \mathrm{C}$ that leads to saving material costs; (2) it reduces the emission of carbon and sulfur dioxides, and (3) it also reduces solid wastes to about $50 \%$. The burning of cement raw material leads to the emission of free silica dust (silicosis), which affects human health (skin diseases, allergies, gastric and duodenal ulcers) especially in laboratories that produce acid-resistant cement; on the other hand, metakaolin does not produce these silicosis dust materials (Environmental Law No. (4) of 1994; International Finance Corporation (World Bank Group) Environmental health and safety guidelines (EHS) for cement manufacturing and lime 2007).

Industrial wastes may supply the largest volumes of toxic materials $\left(\mathrm{CO}_{2}, \mathrm{SO}_{3}\right.$, and $\left.\mathrm{NO}_{2}\right)$, and municipal waste is far from harmless (Montgomery 2008). The production of metakaolin reduces the solid waste content and gaseous pollutants (NOx, $\mathrm{SOx}, \mathrm{CO}_{2}, \mathrm{Hx}, \mathrm{CO}$ ) that resulted from the combustion of the fuel energy. These gases and solid wastes are considered the most important and dangerous on the environment owing to the production of 2000 tons of clinker producing 50 tons of solid wastes (Cement Industry Inspection Manual 2002; Mekkawi 2016). In the present study, the total replacement of cement by geopolymers ( $\mathrm{MK}, \mathrm{NaOH}$, and $\mathrm{NaSiO}_{2}$ ) gave a suitable result similar to the cement in the concert industry. Therefore, these procedures match with green building material. Geopolymers are considered an eco-friendly natural building material and have similar cementing characteristics as Portland cement. Geopolymerization technology was introduced as an ideal and new environmentally friendly process for producing natural supplementary materials accomplished with OPC (Davidovits 1988).

\section{Conclusions}

Based on the obtained results from the current study, the following conclusions can be drawn: 
- Mineralogical, chemical, and thermal characterization of the kaolin deposits has been done on the Upper Cretaceous Timsah Formation. The mineralogical data showed that kaolinite is the dominant clay mineral, followed by quartz, anatase, and iron oxide as non-clay minerals and the kaolinite has a book-like shape. Besides, the chemical composition of the studied kaolin samples is composed mainly of $\mathrm{Al}_{2} \mathrm{O}_{3}$, and $\mathrm{SiO}_{2}$, with minor impurities of $\mathrm{Na}_{2} \mathrm{O}, \mathrm{K}_{2} \mathrm{O}, \mathrm{CaO}, \mathrm{Fe}_{2} \mathrm{O}_{3}, \mathrm{MnO}, \mathrm{TiO}_{2}$, and $\mathrm{MgO}$.

- The kaolinite-bearing layers are considered the weathering products of the surrounded Precambrian basement rocks and the depositional conditions of kaolin deposits reflected the operating, morpho-hydrodynamic regime, which was most likely related to climatic/tectonic conditions.

- The differential thermal and thermogravimetric analyses of the studied kaolin samples have a very low content of carbonaceous materials as revealed by XRF analysis where the samples have a low content of calcium and magnesium oxides, which makes these samples safe in the thermal treatment processes.

- Cement substitution by MK at $10 \%$ and $15 \%$ gives a rise in compressive strength results about $36 \%$ and $22.7 \%$ at 28 days, respectively, and can enhance the characteristics of the produced concrete. Besides, mineral admixtures (e.g., MK) improved compressive strength obviously due to reducing pore space, permeability, and fast reactive nature during the early ages of curing.

- The geopolymer concrete samples have shown compressive strength close to the reference (control) mix results. In addition, the strength results of geopolymer pastes treated for $24 \mathrm{~h}$ at $60{ }^{\circ} \mathrm{C}$ are considerably higher than those treated for $6 \mathrm{~h}$ at $80^{\circ} \mathrm{C}$.

- MK is used as a natural pozzolanic (e.g., supplementary cementitious materials) in control mix, according to high reactivity and is considered a good geopolymer composite (green materials) to reduce the $\mathrm{CO}_{2}$ emissions, reduce energy consumption originating in cement production, and contribute to finding new alternatives to sustainable development.

Acknowledgements The authors gratefully acknowledge Dr/Ahmed Wahid, at the Sweillem Vitrified Clay Pipes Company in Egypt, for his effort in the thermal treatment and calcination process on kaolinite samples. Special thanks to both engineer Mohammed Hijjy and engineer Mohammed Abd El-Halim (El-Bedaya Ready Mix Batch plant), for the laboratory facility and the problem-solving for pouring and curing concrete cubes. The authors would like to express their sincere thanks to the AJGS editorial team, including the AE, Editor-in-Chief, and Journal Manager.

Funding Open access funding provided by The Science, Technology \& Innovation Funding Authority (STDF) in cooperation with The Egyptian Knowledge Bank (EKB).

\section{Declarations}

Conflict of interest The authors declare no competing interests.

Open Access This article is licensed under a Creative Commons Attribution 4.0 International License, which permits use, sharing, adaptation, distribution and reproduction in any medium or format, as long as you give appropriate credit to the original author(s) and the source, provide a link to the Creative Commons licence, and indicate if changes were made. The images or other third party material in this article are included in the article's Creative Commons licence, unless indicated otherwise in a credit line to the material. If material is not included in the article's Creative Commons licence and your intended use is not permitted by statutory regulation or exceeds the permitted use, you will need to obtain permission directly from the copyright holder. To view a copy of this licence, visit http://creativecommons.org/licenses/by/4.0/.

\section{References}

Abdul Ghayoor K, Bazid K (2017) Effect of partial replacement of cement by a mixture of glass powder and silica fume upon concrete strength. Int J Eng Works Kambohwell Pub Ent 4 (7): 124 135. https://hal.archives-ouvertes.fr/hal-01569488

Akinyele JO, Odunfa SO, Famoye AA, Kuye SI (2017) Structural behavior of metakaolin infused concrete structure. Niger J Technol (NIJOTECH) 36(2):331-338. https://doi.org/10.4314/njt.v36i2.2

Ali AA, Elmoaty AM, Emam MA (2019) Factors affecting the mechanical properties of alkali-activated ground granulated blast furnace slag concrete. Constr Build Mater 197:339-355. https://doi.org/ 10.1016/j.conbuildmat.2018.11.086

Ali AR (2014) Cement replacement materials. Properties, durability, sustainability. Springer Geochemistry/Mineralogy, 345p. http:// www.springer.com/series/10171

American Standard for Testing Materials (A.S.T.M) C-109M-12 (2012) Standard test method for compressive strength of hydraulic cement mortars. ASTM International, West Conshohocken, PA, USA. www.astm.org

American Standard for Testing Materials (A.S.T.M) C-143/C-143M05a (2005) Standard test method for slump of hydraulic-cement concrete, 3p. www.astm.org

American Standard for Testing Materials (A.S.T.M) C-192/C-192M-07 (2007) Standard practice for making and curing concrete test specimens in the laboratory, $8 \mathrm{p}$. www.astm.org

American Standard for Testing Materials (A.S.T.M) C-494/C-494M05a (2005) Standard specification for chemical admixtures for concrete, 9p. www.astm.org

Araco for Building Materials and Contracting, Cairo, Egypt. SP30 Type-G (enhance the concrete workability and its mechanical strength properties).

Arioz O, Tuncan M, Arioz E, Kilinc K (2006) Geopolymer: a new generation construction material. 31st Conference on Our World in Concrete and Structure. Singapore, 4p. https://cipremier.com/100031012

Attia MI (1955) Topography, geology and iron-ore deposits of the district east of Aswan: Cairo. Special Publication, Egypt. Annals Geological Survey of Egypt, p 262p

Baioumy H, Gilg HA (2011) Pisolitic flint kaolin from Kalabsha, Egypt: A laterit-derived facies. Sed Geol 236(1-2):141-152. https://doi.org/10.1016/j.sedgeo.2011.01.002

Barbosa VF, Mackenzie KJ (2003b-b) Thermal behavior of inorganic geopolymers and composites derived from sodium polysialate. Mater Res Bull 38 (2): 319-331. https://doi.org/10.1016/S00255408(02)01022-X

Bentabol M, Ruiz Cruz MD, Huertas FJ, Linares J (2006) Hydrothermal synthesis of $\mathrm{Mg}$ and $\mathrm{Mg}-\mathrm{Ni}$-rich kaolinite. Clays and Clay 
Mineral 54: 667-677British Standard No.12350-2 (2000) Method specification for testing fresh concrete Part 2: Slump test. The European Standard EN-12350-2:1999 has the status of a British Standard. 12p. https://doi.org/10.1346/CCMN.2006.0540602

British Standard No. 12350-part 2 (2000) Method specification for testing fresh concrete (Slump test). The European Standard EN-12350-2:1999 has the status of a British Standard. 12p.

British Standard No.1881-part 108 (1983) Method for making test cubes from fresh concrete.

British Standard-European Standard No.1881-part 115 (1986) Method specification for compression testing machines for concrete. BS-EN: 12390-4-2000.

Carozzi AV (1960) Microscopic sedimentary petrography. John Wiley \& Sons INC., New York

Cement Industry Inspection Manual (2002) Ministry of State for Environmental Affairs Agency, 79p. http://industry.eeaa.gov.eg/ publications/Cemen\%20IM-2003.pdf

Consultants W-C (1985) Earthquake activity and stability evaluation for the Aswan high dam. Unpublished report, High Aswan and Dam Authority, Ministry of Irrigation, Egypt

Davidovits J (1988) Geopolymer chemistry and properties. Geopolymer 88. First European Conference on Soft Mineralurgy, Compiegne, France 1:25-48

Davidovits J (1991) Geopolymers: inorganic polymeric new materials. J Therm Anal 37:1633-1656

Davidovits J (1994) Geopolymer: inorganic polymeric new materials. J Mater Educ 16:91-139

Davidovits J (1999) Chemistry of geopolymeric systems. In: Terminology. Geopolymer 99, Second International Conference, Saint-Quentin, France, 9-39.

Duxson P, Lukey G, Van Deventer J (2007) The thermal evolution of metakaolin geopolymers, part 2-phase stability, and structural development. J Non-Cryst Solids 353:2186-2200

Duxson P, Lukey G, Separovic F, Van-Deventer J (2005) Effect of alkali cations on aluminum incorporation in geopolymeric gels. Ind Eng Chem Res 4(44): 832-839

Egyptian Standard No.1658 (1988) Part 1, a method for taking the fresh concrete sample in site and determination of fresh concrete slump, 13p

Egyptian Standard No.1658 (1991) Part 5, a method for making test cubes, $6 \mathrm{p}$, and part 7 method for determination of compressive strength of hardened concrete specimens, 43p

El Kelany A, Said M (1990) The geology of Wadi Kalabsha area, western Desert. Egypt Annals of Geol Survey of Egypt 16:337-339

El-Askary MA (1992) Petrography and origin of the pisolitic kaolinite deposits of Wadi Kalabsha, Upper Egypt. N Jb Geol Paläont Abh 185(3):329-348

El-Desoky H, Farouk S, Heikal M, El-Mahallawy M, Wahid A (2019) Geochemical and technical investigation of some clay materials in the Bahariya Oasis, Western Desert, Egypt: implication in the vitrified clay pipes industry. J Afr Earth Sc 160(103612):17. https:// doi.org/10.1016/j.jafrearsci.2019.103612

El-Shazly MS (1954) Rocks of Aswan area. Governmental Press

Embaby AK (2017) Optimizing Wadi Kalabsha kaolin ore grade by GIS for uses in Egyptian ceramic and refractory industries. International Journal of Scientific and Engineering Research 8 (1): 1162-1171. https://www.ijser.org/researchpaper/OptimizingWadi-Kalabsha-kaolin-Ore-Grade-by-GIS-for-Uses-in-Egypt ian-Ceramic-and-Refractory-Industries.pdf

Farouk S, El-Desoky H, Heikal M, El-Mahallawy M, Wahid A (2020) Egyptian Cretaceous clay deposits: insights on mineralogy, geochemistry, and industrial uses. Arab J Geosci 13(556):22. https:// doi.org/10.1007/s12517-020-05557-7

Fischer K (1989) Prozesse und produkte lateritischer Verwitterung in oberkretazischen sedimenten oberägyptens und des Nordsudan. Berliner Geowissenschafliche Abhandlungen (a) 115:123
Fitzpatrick EA (1980) Soils. Their formation, classification, and distribution. 2nd edition. Longman, London, 453p

Folk RL (1980) Petrology of sedimentary rocks. Hemphill publishing company, Austin, p 184p

Földvári M (2011) Handbook of the thermogravimetric system of minerals and its use in geological practice. Geological Institute of Hungary, Budapest 213:180 (ISBN 978-963-671-288-4). https:// mek.oszk.hu/18000/18031/18031.pdf.

Geological map of AS SADD Al ALI (High Dam) Quadrangle, Egypt. Egyptian Geological Survey (EGSMA): an atlas of western desert., scale 1:250.000, sheet NF-36N (2005).

Germann K, Mücke A, Fischer K (1987) Late Cretaceous laterite derived sedimentary deposits (oolitic ironstone, kaolins, and bauxite) in Upper Egypt. Berliner Geowissenschafliche Abhandlungen (A) 75(3): 727-758. http://repository.sustech.edu/bitst ream/handle/123456789/13073//D8/AA/D8/A3/D8/AB/D9/80/ D9/8A/D8/B1/20/D8/B5/D9/86/D8/A7/D8/B9/D8/A9/20/D8/ A7/D9/84/D8/A7/D8/B3/D9/85/D9/86/D8/AA/20....pdf?seque nce $=1 \&$ isAllowed $=y$

Hamimi Z, Hagag W, Osman R, El-Bialy M, Abu El-Nadr I, Fadel M (2018) The active Kalabsha Fault Zone in Southern Egypt: detecting faulting activity using field-structural data and EMRtechnique, and implications for seismic hazard assessment. Arab J Geosci 11:421. https://doi.org/10.1007/s12517-018-3774-1

Hassaan MM, Khater HM, El-Mahallawy MS, El Naggar AM (2015) Production of geopolymer composites enhanced by nano-kaolin material. Journal of Advanced Ceramics 4(4):245-252. https:// doi.org/10.1007/s40145-015-0156-y

Hinckley ND (1965) Mineralogical and chemical variations in the kaolin deposits of the coastal plain of Georgia and South Carolina. Am Miner 50:1865-1883

International Finance Corporation (World Bank Group) General Environmental, health, and safety guidelines (EHS) for cement manufacturing and lime (2007), p. 99. https://www.ifc.org/wps/ wcm/connect/29f5137d-6e17-4660-b1f9-02bf561935e5/Final\% 2B-\%2BGeneral\%2BEHS\%2BGuidelines.pdf?MOD=AJPERES\& $\mathrm{CVID}=\mathrm{nPtguVM}$

Issawi B (1969) The geology of Kurkur-Dungul area. Egyptian Geological Survey, Paper 46, p. 102

Issawi B (1973) Nubia sandstone: type section. AAPG Bull 57(4):741-745

Issawi B (1978) Geology of Nubia west area, Western Desert. Egypt Annals Geological Survey of Egypt 8:237-253

Issawi B (1982) Geology of the Southwestern Desert of Egypt. Annals Geological Survey of Egypt.

Issawi B (1987) Geology of the Aswan Desert. Annals Geological Survey of Egypt.

Khater HM, Ezzat M, El Nagar AM (2016) Alkali activated ecofriendly metakaolin/slag geopolymer building bricks. Chemistry and Materials Research 8(1):21-32

Khater HM, El Nagar AM (2019) Combination between organic polymer and geopolymer for production of eco-friendly metakaolin composite. J Aust Ceram Soc 56:599-608. https://doi.org/10. 1007/s41779-019-00371-1

Kretz R (1983) Symbols for rock-forming minerals. Am Miner 68:277-279

Lahiba I, Sardar KR, Shazim AM, Muhammad KK, Muhammad FJ (2020) A review of recent developments and advances in ecofriendly geopolymer concrete. Appl. Sci. MDPI, 10, 7838, 56p. https://doi.org/10.3390/app10217838

Master Builders Solution (Admixture systems) construction chemicals (S.A.E), Egypt. Hyperplasticizer Glenium for water-reducing properties of supplementary cementitious materials. www.masterbuilders-solutions.com/en-eg

Mekkawi HS (2016) The impact of the cement industry on safety and public health: a case study of Atbara Cement Company. Sudan 
University of Science and Technology, College of Graduate Studies, 119p. http://repository.sustech.edu/handle/123456789/13073

Montgomery CW (2008) Environmental geology. McGraw-Hill, New York. 9th ed. 374p. https://www.amazon.com/EnvironmentalMontgomery-published-McGraw-Hill-Engineering/dp/B00E2 8GZSM. https://www.academia.edu/14439692/environmental_ geology

Murray HH, Janssen J (1984) Oxygen isotopes indicators of kaolin genesis. Proceedings of the 27th International Geological Congress. Non-metallic mineral ores. VNU Science Press 5: 287-303

Nadhir TS, Oussama B, Kamil K, Łukasz S (2020) Ultrasonic evaluation of cement-based building materials modified using marble powder sourced from industrial wastes. Buildings 10(38):16. https://doi.org/10.3390/buildings10030038

Ng C, Johnson UA, Leong SW, Kim HM, Mohd ZJ, Ramesh S (2018) A review on the microstructural study and compressive strength of geopolymer mortar, paste, and concrete. Constr Build Mater 186:550-576. https://doi.org/10.1016/j.conbuildmat.2018.07.075

Patankar SV, Ghugal Y, Mand Jamkar SS (2018) Effect of concentration of sodium hydroxide and degree of heat curing on fly ash based Geopolymer mortar. Indian J Mater Sci 2014:1-6

Provis JL, Duxson P, Van Deventer JS (2010) The role of particle technology in developing sustainable construction materials. Adv Powder Technol 21:2-7

Railsback LB (2003) An earth scientist's periodic table of the elements and their ions. Geology 31:737-740

Saber E, Ali M, El-Sheikh A (2018) Provenance studies of Kalabsha kaolin deposits, Egypt: a petrographical and geochemical approach. Arabian J Geos 11(339):15. https://doi.org/10.1007/ s12517-018-3690-4

Sabir BB, Wild S, Bai J (2001) Metakaolin and calcined clays as pozzolans for concrete: a review. Cement Concrete Composites 23:441-454

Said R, Mansour AO (1971) An introduction (The discovery of a new kaolin deposit in Wadi Kalabsha, Nubia. Egypt). Geol Surv Egypt Paper no. (54), 138.

Shakir AA, Amer MI, Zeinab HN (2013) The effect of nano metakaolin material on some properties of concrete. Diyala J Eng Sci 6(01):50-61

Shashikant UG, Prince Arulraj GA (2019) Research article on geopolymer concrete. Int J Innov Technol Explor Eng (IJITEE), 8(9S2), 4p. https://doi.org/10.35940/ijitee.I1106.0789S219.
Strakhov NM (1962) Principles of lithogenetic theories. V. II. Translated from the Russian (1962) by J. Paul Fitzsimmons and edited by S. I. Tomkieff and J. E. Hemingway. 609 pp., 222 figs. Consultants Bureau, New York; Oliver and Boyd, Edinburgh. Geol Mag 108 (1): 77-78. https://doi.org/10.1017/S0016756800051050

The Arab Republic of Egypt, the Cabinet of Ministries, Ministry of State for Environmental Affairs, Egyptian Environmental Affairs Agency, Helwan Cement Factories. According to Environmental Law No. (4) of 1994 regarding environmental protection and its implementing regulations, as amended by Law No. (9) of 2009. http://www.eeaa.gov.eg/en-us/laws/envlaw.aspx

Tironi A, Trezza MA, Irassar EF, Scian AN (2012) Thermal treatment of kaolin: 1251 effect on the pozzolanic activity. Procedia Materials Science 1:343-350

Vemundla R, Koniki S (2020) Mechanical properties and mix design of geopolymer concrete. A review. E3S Web of Conferences 184, 01091 (ICMED), 5p. https://doi.org/10.1051/e3sconf/2020184010 91

Welton JE (1984) SEM Petrology Atlas. Chevron Oil Field Research Company (Methods in Exploration Series No. 4). The American Association of Petroleum Geologists. Tulsa, Oklahoma 74101, U.S.A. 247p. (ISBN 10: 0891816534 ISBN 13: 9780891816539 ). https://www.amazon.com/SEM-Petrology-Atlas-Joanne-Welton/ $\mathrm{dp} / 1588612147$

Whitney D, Evans B (2010) Abbreviation for names of rock-forming minerals. Am Miner 95:185-187

Wild S, Khatib JM, Jones A (1996) Relative strength, pozzolanic activity, and cement hydration in superplasticizer Metakaolin concrete. Cement Concrete Research 26(10):1537-1544

Yao X, Zhang Z, Zhu H, Chen Y (2009) Geopolymerization process of alkali-metakaolinite characterized by isothermal calorimetry. Thermochim Acta 493(1/2):49-54

Youssef AAS (1996) Sedimentological studies on the central Wadi Kalabsha kaolin deposits, southwest of Aswan. Egypt J Mineral Petrol Econ Geol 91:353-363

Zain H, Mustafa M, Hussein K, Ariffin N, Bayuaji R (2017) Review on various types of geopolymer materials with the environmental impact assessment. MATEC Web of Conferences 97(01021):10p. https://doi.org/10.1051/matecconf/20179701021 